\title{
Equity in Educational Expenditures: Can Government Subsidies Help?
}

\author{
Jishnu Das*
}

\begin{abstract}
When there are externalities across households, governments can improve economic outcomes by equitably subsidizing education. But this chain of causality works only if (a) allocated resources reach the final recepients and (b) equity in public subsidies translates directly into equity in total educational expenditures, including private spending at the household level. Using a unique data set from Zambia, this paper shows that whether these condtions are met depends on the specific schemes used to allocate resources as well as the exact form of the subsidies. First, subsidies allocated through clear guidelines and legislated rules reached the final recepients but those allocated at the discretion of province and educational offices did not. Second, even those components of subsidies that were progressive (in that the share of total subsidies to the poor was greater than the share of the nonpoor) had no effect on inequality in total educational expenditures due to the crowding out of household spending.
\end{abstract}

*DECRG, The World Bank. I thank Quy-Toan Do, Francisco Ferreira, Xavier Gine, Tara Vishwanath and Dominique Van de Walle for helpful comments and discussions. This study is part of a larger project on educaton in Zambia in collaboration with Stefan Dercon, James Habyarimana and Pramila Krishnan. Funding for the survey was provided by the UK Department for International Development (DFID). The findings, interpretations, and conclusions expressed in this paper are those of the author(s) and do not necessarily represent the views of the World Bank, its Executive Directors, or the governments they represent. Working papers describe research in progress by the author(s) and are published to elicit comments and to further debate.

E-mail address: jdas1@worldbank.org 


\section{Introduction}

In the context of poverty traps and multiple equilibria, educational subsidies can provide the initial impetus for shifting an economy to a desirable equilibrium (Banerjee 2003 and Galor and Zeira 1993). Moreover, allocative equity can enhance allocative efficiency (Fernandez and Rogerson 1996 and Epple, Filimon, and Romer 1984). Externalities in education result in concave returns for the social planner so that higher equity in educational expenditures generates higher levels of welfare.

Apart from efficiency gains, there are strong moral and ethical reasons for supporting equality in educational expenditures. For instance, an important position on education in the United States argues that "A system that allows the accidents of geography and birth to determine the quality of education received by an individual is inimical to the idea of equal opportunity in the marketplace" (Fernandez and Rogerson 1996). Taken together these studies suggest that governments should subsidize educational expenditures and to the extent that household expenditures on education are inherently unequal, governments should try to attenuate the differences between rich and poor households through appropriate financing programs. ${ }^{1}$

Consider a social planner seeking to maximize a welfare function that is concave in educational expenditures, with a financing constraint. Educational expenditures in turn are composed of government subsidies and household (private) spending on education. The maximizing solution allocates government subsidies so that total educational expenditure is equalized for every agent. What constraints does a government face in delivering such an outcome? Three issues arise. First, government functionaries may not act as "benevolent" entities when collecting taxes and distributing education subsidies (the "helping-hand" characterization of the state). Frye and Shleifer (1997) for instance, argue for a "grabbing hand" view with independent bureaucrats pursuing their own agenda. Policy implications differ: under the grabbing-hand view, government intervention may be less desirable than the constrained optimal obtained through the private market.

The second issue is the ability of the government to target expenditures at a disaggregated level. Although ideally the government may wish to target educational subsidies to households, feasibility constraints restrict what the government can and cannot do. In this case, a second-best scheme may be followed where targeting is at the level of the school rather than the household. The success of such a scheme would then depend on the distribution of wealth within and between schools. In particular, if all inequality is due to inequalities between schools, there is no loss from targeting at the level of the school.

Household responses to government subsidies also matter. Generically, household spending on education will depend both on its income and the amount of government transfers received. The effect of government transfers on overall inequality will therefore depend on the extent of crowding-out (or crowding-in) at different levels of the income distribution and the post-transfer distribution of educational expenditures may be very different from what would arise without any household responses.

This paper uses a unique data set on primary education from Zambia to examine these issues and the following questions: ${ }^{2}$

\footnotetext{
${ }^{1}$ See Hoxby (1995) for a contrasting view on how equity in school subsidies may decrease efficiency in the context of assymetric information.

${ }^{2}$ The data was collected by the author in collaboration with Stefan Dercon, James Habyarimana and Pramila Krishnan
} 
1. Do resources allocated by the central authority actually reach intended recipients (and if so, under what conditions)?

2. Does school-based targeting adequately meet equity objectives?

3. Conditional on receipt, do such resources decrease inequalities in total educational expenditure?

Educational expenditures in Zambia (apart from teacher salaries - see below) are distributed through an administrative hierarchy consisting of Provincial Educational Offices and District Educational Offices. The survey data contain a detailed tracking of resources allocated by the government through this hierarchy to schools as well as information on household assets of 20 randomly selected students from every school. This paper uses the combination of expenditure tracking and school wealth to examine the first two questions. Moreover, the survey also contains data on educational expenditures of households matched to resources received at the school that children in the household attend. This unique matched data is used to examine household responses to government transfers.

The analysis is simplified by the specific resources that schools received during the survey year. Although schools could receive three distinct types of inputs - in-kind receipts in the form of textbooks or chalk, staff salaries and cash grants - during the year of the survey, they received little in-kind inputs (on average less than 0.05 textbooks, 0.012 desks, 0.001 chairs and 0.01 boxes of chalk per student). ${ }^{3}$ Moreover, teacher remuneration was sent directly as payroll checks from the center to individual teachers eliminating any potential for diversion. One can thus concentrate entirely on cash grants as the relevant government transfer.

The findings show that the success of government subsidies in reducing educational inequalities depends on institutions, the structure of resource allocation, and the types of expenditures that the resources were used for. Cash grants allocated through clear guidelines and rules reached schools in the earmarked fashion. Moreover, due to the particular distribution of wealth within and across schools, targeting at the school level was successful. The distribution was progressive with the poorest quintile receiving 30 percent of all funds. In contrast, a much smaller percentage of cash grants allocated through the discretion of district and provincial offices reached schools and there is no evidence that these were allocated in a progressive manner. Incorporating teacher salaries, the overall system of financing is regressive, with the lowest 40 percent receiving less than 35 percent of overall funds allocated to schools.

This inequity in public financing, however, is dwarfed by that in private (household) expenditures on educational items with the poorest 40 percent spending less than 20 percent of the total. With these high levels of inequality in household level expenditure, cash grants, which accounted for 30 percent of total expenditures (including private spending) and were highly progressive could potentially serve as an equalizing transfer. Unfortunately, these grants crowded out private household expenditure and the extent of substitution was greater among the poor than the non-poor. Consequently the transfers had (at best) no effect on reducing inequality in overall educational expenditures.

\footnotetext{
${ }^{3}$ This was largely due to problems in the planning department of the Ministry of Education coupled with problems in procurement, rather than due to the lack of funds (less than 60 percent of the allotted budget was actually used during the fiscal year).
} 
The results have important implications. In a ranking of 102 countries by Transparency International, Zambia ranked 77th in the Corruption Perception Index scoring a low 2.6 out of a possible 10 (Transparency International 2002). The findings imply that despite the poor structure of overall governance, resources can be efficiently and equitably allocated to recipients if delivery mechanisms are well designed. Exactly the same conclusions hold regarding the impact of subsidies on inequalities in educational expenditure. This impact depends as much on what the subsidy is for as the amount of the subsidy itself. A flexible form of subsidy - unrestricted cash grants - have little effect on inequality in total educational expenditures due to the crowding out of household-level expenditures at all levels of income. One way to interpret these results is that schools are constrained in what they can do and are hence unable to spend cash grants optimally. These constraints could arise either due to thin markets (for instance in the case of teachers) or lack of scale economies (for instance to improve infrastructure).

The work gains special relevance in the context of fiscal target setting under, for instance, the Millennium Development Goals of international institutions such as the World Bank. The results suggest that fiscal targets, while important, may not have the desired impacts unless careful consideration is given to the patterns of disbursement and the types of expenditure that such programs entail. This paper mirrors the results found in Das and others (2004) who examine the efficiency implications of the cash-grants in terms of learning outcomes. They find that anticipated cash grants (studied here) have no impact on learning achievement. The results presented here suggests that these grants can be used as an effective means of targeting resources to the poor, but crowding out of household expenditures implies that there is no effect on the inequality of overall educational expenditures either.

The remainder of the paper is structured as follows. Section 2 discusses the related literature and draws a parallel to studies of benefit incidence for public services. Section 3 presents a theoretical structure to understand the relationship between school and household inputs. Sections 4 presents the data and Section 5 presents the results. Section 6 concludes.

\section{Related Literature}

This paper relates to three strands of the literature. The first is research on benefit incidence, the second strand is work on the role of institutions and governance in determining outcomes and the third studies household responses to subsidies provided by the government and other agencies.

\subsection{Benefit Incidence}

In a recent paper Van de Walle (2003) discusses different approaches to evaluating the welfare impact of a program. In the benefit-incidence approach the costs of providing services are assumed to reflect the benefits received by the users. These costs are then ranked by welfare criteria to provide, for instance, the extent of government spending on the poorest quintile in a given country. Since data is normally available for a sub-sector (or at most, disaggregated by regions and sub-sectors) variation in the subsidy is entirely a reflection of underlying variation in access to the service by different population subgroups. For instance, the cost of providing primary education might be computed for an entire country. Differences in the percentage 
spent on the poor compared to the rich arise due to the number of poor and rich individuals who access primary education.

According to van de Walle $(1998,2003)$, this approach suffers from several problems. First, constructing the counterfactual welfare distribution in the absence of the program is key. Second, the implicit assumption that costs of services directly reflect on benefits is problematic if the marginal impact of spending has differential effects on welfare for different individuals. This paper addresses the problems raised by Van de Walle (2003) by using detailed micro level information on institutions and delivery mechanisms (for an earlier example see Hammer and others 1995). The study argues that responses to government subsidies by households can be interpreted as causal, so that the "counterfactual" expenditure distribution is econometrically identified. Second, it verifies that the size of the subsidy does not reflect on benefits, if benefits are defined

as proportional to total expenditure on education; it is acknowledged that this still does not fully address the question of welfare since there could have been increased expenditure on other goods such as health.

\subsection{Institutions and Outcomes}

The second strand of literature, which relates to the role of institutions has been empirically examined by Acemoglu, Johnson, and Robinson (2001), Burnside and Dollar (2000), and Frye and Shleifer (1997). This work demonstrates that institutions matter. Burnside and Dollar (2000), for instance, show that the effectiveness of aid is tempered by the nature of governance in the country - effectiveness is greater in countries where governance indicators are better (for a more nuanced view see Easterly (2003)). Along a similar vein, but at a more disaggregated level, Frye and Shleifer (1997) and Djankov and others (2002) have studied property rights and the effectiveness of courts. They find that cross-country differentials in the enforcement of such rights is associated with growth patterns across countries. Finally, Acemoglu, Johnson, and Robinson (2001) address the problem of endogeneity in institutional variation across countries and show that accounting for the endogeneity of institutional characteristics does not change the fundamental result that institutions matter for economic outcomes.

While these studies all concentrate on differentials across countries, this paper shows that variation in the design of allocation schemes within the country also matters. This view is closer to an older literature on project design and more recent papers by Khwaja (2002) and Reinikka and Svensson (2002). Khwaja (2002) shows that the degree to which projects are maintained depends as much on the characteristics of the community as the design of the project. For instance, a project with higher community participation in the construction phase was more likely to be well-maintained compared to a project with less participation in the same community. Similarly, Reinikka and Svensson (2002) show that allocated resources are more likely to reach schools if there is clear information regarding the amount distributed.

\subsection{Household Responses}

Finally, this study also relates to the literature on household responses to government subsidies. The research on this front has examined labor supply decisions (Moffitt 1992, Ravallion and Datt 1995) and private transfers to households (Cox and Jimenez 1995, Rosenzweig and Wolpin 1994) to find that the effect 
of government subsidies is generally attenuated through the presence of household responses. There is, however, a gap in the literature on household responses to school inputs, perhaps due to tricky sampling issues. An exception is Jacoby (2002), who relates the caloric intake of children at home to calories provided by a school feeding program. Jacoby (2002) shows that the school-feeding program had a "flypaper" effect whereby extra calories at the school were not substituted away by decreased consumption at home. The results presented here contrast with Jacoby's, in that substitution vis-à-vis cash grants received by the school are large and significant.

\section{A Simple Theoretical Structure}

The following model structures the empirical results. To study the impact of government subsidies on inequality in educational expenditure, the theory shows how the extent of substitution can differ across the rich and the poor, once we incorporate a production function for educational attainment into a household optimization problem. ${ }^{4}$ With this approach, the budget constraint is non-linear so that the price implications of an in increase in government subsidies can differ for the rich and the poor.

Consider a household with one child that maximizes utility from two goods, education $(E)$ and "other goods" $(X)$, in a single period subject to a budget constraint. The household cannot spend directly on education; education is determined through a production function, $E=g\left(w_{s}, z_{h}\right)$, where $w_{s}$ are inputs at the school level and $z_{h}$ are inputs at the household level. Thus, the household affects education levels only through its purchases of $z_{h} ; w_{s}$ must be provided by the government. The maximization problem is:

$$
\begin{aligned}
& \operatorname{Max} U(E, X) s . t \\
. E= & g\left(w_{s}, z_{h}\right) \\
Y= & z_{h} P_{z}+X P_{x} .
\end{aligned}
$$

Assuming an interior solution (more on this below), first-order conditions are given by

$$
\frac{\frac{\partial U}{\partial E} \frac{\partial E}{\partial z_{h}}}{\frac{\partial U}{\partial X}}=\frac{P_{z_{H}}}{P_{x}} .
$$

The difference with a standard optimization problem is the inclusion of the additional term $\frac{\partial E}{\partial z_{h}}$, which is interpreted as a price effect in the following sense. Consider the effect of consuming an additional unit of $X$. The consumption of $E$ given up in a standard problem is then $P_{x} / P_{E}$ and first-order conditions imply indifference in equilibrium between consuming an extra unit of $X$ or $E$. Once $E$ is determined through a production function, however, the decrease in $E$ is no longer given by the price ratio. As before, consuming an additional unit of $X$ will decrease consumption of $z_{h}$ by $P_{x} / P_{z}$, but now this translates into a decrease in $E$ through the marginal product of $z_{h}$ at that particular point, given by $\partial E / \partial z_{h}$ in Equation (2) above. Incorporating a production function in the optimization framework implies that the budget constraint is no

\footnotetext{
${ }^{4} \mathrm{~A}$ model along the same lines is also presented in Brown (2003). However, we differ from Brown (2003) in the specific question asked. While Brown is interested in the relationship between parental education and child achievement, the central issue here is the relationship between school and household inputs.
} 
longer (necessarily) linear - the additional $X$ that can be consumed by forsaking one unit of $z_{h}$ will vary with the level of $z_{h}$. This is clarified in Figure 1.

The two panels in Figure 1 show the preference and the production function space. Since preferences are defined over $E$ and $X$, indifference curves are derived in the usual fashion (assuming quasiconcavity of $U()$.$) . The budget set, however, is derived from the production function space. The isoquants in Panel B$ correspond to a convex production set, where increases in $z_{h}$ at constant levels of $w$ decreases the marginal product of $z_{h}$. This is directly reflected in the concavity of the budget constraint. At high levels of $z_{h}$ (and therefore $E$ ), decreasing $E$ leads to large increases in $X$, and this gain declines as the consumption of $E$ increases.

The second budget constraint $(w>0)$ shows that increasing $w_{s}$ has the standard impact of an income subsidy by shifting the budget constraint outwards. In addition though, there is also a price effect measured by the change in slope at any given $X$ value. Household responses will then depend on the income effect, measured by movements along an Engle curve, and the price effect reflecting a change in the implicit price (measured by the change in the marginal product along the production function) of an increase in $w_{s}{ }^{5}$

The nature of the income effect is well understood. If the marginal propensity to consume $E$ out of additional income decreases with income, poorer households will respond less to increases in $w_{s}$ than their richer counterparts (so that there will be a larger increase in their overall educational spending). Thus, increases in $w_{s}$ favor a more equitable distribution of educational expenditures, with the opposite result if the marginal propensity to consume $E$ rises with income.

To concentrate on the price effect the rest of this section assumes that subsidies are externally financed externally (say through donors) and there are two types of agents, equally represented in the population, with Cobb-Douglas preferences who differ only in income - poor $\left(Y_{p}\right)$ and rich $\left(Y_{r}\right)$. With homothetic preferences, in a standard optimization framework (without a built in production function) the expenditure share of the poor compared to the rich is $Y_{p} / Y_{r}$ (population proportions of rich and poor are the same) and the results below can be interpreted as arising from the "pure" price effect through the production function.

\subsection{Example 1: Zero Price Effects}

Consider the following specification of utility and the production function:

$$
\begin{aligned}
U(E, X) & =E^{\beta} X^{1-\beta} \\
E & =w_{s}+z_{h} .
\end{aligned}
$$

In this formulation, $w_{s}$ and $z_{h}$ are perfect substitutes in the production function. This implies both that isoquants are linear and that increases in $w_{s}$ have no effect on the slope of the budget constraint - the price effect is eliminated. As expected with no price effect, increases in $w_{s}$ are fully internalized as an increase

\footnotetext{
${ }^{5}$ An immediate question is the conditions under which the budget set is non-convex. Clearly, this happens if the marginal product of $z_{h}$ increases in $z_{h}$. Therefore, particular care needs to be taken to ensure that second-order conditions are met in the maximization problem. In particular, some combinations of production and utility functions will display "all or nothing" solutions.
} 
in income. Solving this program with the budget constraint and assuming for simplicity $P_{X}=P_{z_{h}}=1$, we have

$$
z_{h}^{*}=\beta\left(Y+w_{s}\right)
$$

Since the optimal solution when $z_{h}$ directly enters utility without a production function is given by $z_{h}^{*}=\beta Y, w_{s}$ serves only to augment income.

\subsection{Example 2: Linear Isoquants with Price Effects}

Alternatively, with Equation (3) and the specification

$$
E=w_{s} z_{h}
$$

isoquants are linear, but increases in $w_{s}$ increase the marginal product of $z_{h}$ by exactly the amount of the subsidy $\left(\partial E / \partial z_{h}=w_{s}\right)$. The complementarity of the two inputs in the production function implies that $E$ becomes cheaper with government subsidies. In this case the income effect of the increase in $w_{s}$ combines with the price effect to leave $z_{h}^{*}$ unaffected by the subsidy - all increases in $w_{s}$ translate directly into increases in $E$. The effect of government subsidies on equity is now higher since household responses imply that the full impact of $w_{s}$ is felt in total educational expenditures.

This suggests that greater substitutability between $w_{s}$ and $z_{h}$, will decrease the effect that such subsidies have on equalizing total educational expenditures. This result is not entirely general. Consider the case of Leonteif production functions. In this case zero government subsidies lead to a perfectly equitable distribution of educational expenditures. This equality is retained with initial increases, but at higher-level subsidies increase inequality (providing a shoe for the left foot to all individuals will increase inequality if the poor cannot buy the matching pair, but the rich can). However, to the extent that $w_{s}$ and $z_{h}$ are "somewhat" substitutable, the result holds and this is further explored in the next section.

\subsection{Example 3: Simulations with Constant Elasticity of Substitution Production Functions}

Consider the production function

$$
E=\left(w_{s}^{\alpha}+z_{h}^{\alpha}\right)^{\frac{1}{\alpha}}
$$

where $\alpha \in[0,1]$ is the elasticity of substitution ( $\alpha=1$ is the case given by Equation (4) above). The solution to this program is given by the condition

$$
z_{h}^{*}+\frac{(1-\beta)\left(w_{s}^{\alpha}+z_{h}^{* \alpha}\right)}{\alpha z_{h}^{* \alpha-1}}=Y
$$

To study the role of $\alpha$, distributions of expenditures with $Y \sim N(5000,1500)$ and varying degrees of $w_{s}$ and $\alpha$ are simulated. The simulations assume that $w_{s}$ is distributed equally to all agents and is therefore wealth neutral.

Figure 2 shows the results of this simulation using concentration curves. ${ }^{6}$ The horizontal axis in all graphs

\footnotetext{
${ }^{6}$ The concentration curve is constructed by plotting the share of each population group against the welfare indicator. Thus,
} 
is the income quintile and the vertical axis is the share of total expenditure (the line of perfect equality is the $45^{0}$ line where spending shares are the same for every group). The graph on the upper left shows the effect of increasing government subsidies from $w_{s}=100$ to $w_{s}=1000$ for a production function characterized by low substitutability $(\alpha=0.1$ ). The graph on the right then shows results from the same experiment for a function where $w_{s}$ and $z_{h}$ are highly substitutable $(\alpha=1)$. Finally, the lower graphs show the effect of providing the same subsidy for production functions with different degrees of substitutability. ${ }^{7}$ The figure on the left shows the effect of a subsidy of $w_{s}=500$ and the figure on the right for $w_{s}=1000$ for $\alpha=0.1$ and 1.

Increasing government subsidies has a larger impact on equality in educational expenditures when the elasticity of substitution is low. Increasing $w_{s}$ from 100 to 1000 (20 percent of the mean income) has no discernible impact on inequality for $\alpha=1$, but almost doubles the share of the poorest 5 percent when $\alpha=0.1$ (from 0.027 to 0.044 ). Moreover the gains from increasing government subsidies are much larger when inputs have low substitutability. For instance, when $\alpha=0.1$, the government subsidy, $w_{s}=500$ doubles the share of the poorest 5 percent compared to the same subsidy for an input with $\alpha=1$. This effect increases with the size of the subsidy; if $w_{s}=1000$ the increase in the share of the lowest quintile for $a=0.1$ compared to $\alpha=1$ is now 130 percent. In general, it can be shown that for a fixed $\sum_{i=1}^{n} w_{i}$, equality (defined as $\left.\frac{w_{s}^{\text {poor }}+z_{i}^{\text {poor }}}{w_{s}^{\text {rich }}+z_{i}^{\text {rich }}}\right)$ is decreasing in $\alpha$, so that providing inputs with lower substitutability renders a higher level of utility for the social planner.

This framework shows that the extent to which government subsidies have an effect on inequality depends on the kind of input provided. In particular, there is no a priori reason to assume that government transfers lead to higher substitution by the rich compared to the poor - this depends entirely on the structure of the production function for education. In general, when inputs provided by the government are highly substitutable in the production function there is little impact on inequality in the overall distribution of educational expenditures; results are more positive when inputs provided have lower degrees of substitutability.

The discussion assumes that the allocated grants actually reach schools. Whether or not this happens depends on a number of factors discussed for instance in Bardhan and Mookherjee (2000) and Reinikka and Svensson (2002). The results on this front are descriptive, emphasizing the importance of the design aspect in delivery schemes.

for a group $j$, with $k$ individuals, the share of expenditure is defined as

$$
s_{j}=\frac{\sum_{i=1}^{k} E_{i}}{\sum_{i=1}^{n} E_{i}} .
$$

Typically wealth quintiles or deciles are used to define the population group.

${ }^{7}$ To motivate this, consider the modified CES given by $\left[\left(w_{1 s}^{\alpha}+z_{h}^{\alpha}\right)^{\gamma / \alpha}+w_{2 s}^{\gamma}\right]^{1 / \gamma}$ and the government choosing whether to provide $w_{1 s}$ or $w_{2 s}$. If $w_{1 s}=0$, we have a CES production function with elasticity $\gamma$, and if $w_{2 s}=0$, the elasticity is $\alpha$. 


\section{Data}

\subsection{The Country Context: Education in Zambia}

The data for this study are from Zambia, a landlocked country with a population of 10 million, almost entirely dependant on copper for export revenues. With a decline in copper prices in the 1980s, there was a commensurate decrease in income and government resources. As a result, average real per capita government education expenditure in 1996-98 was only about 73 percent of the 1990-92 level, declining further to an average of about 60 percent of this level by 1999-2000 (World Bank data based on Government of Zambia Financial Statements).

This economy wide decline also had an impact on educational attainment. For instance net primary school enrollment at 72 percent is at an historically low level, having seen some decline during the previous decade $^{8}$ Both the government and households have responded to this worsening of the education profile. The government initiated a Basic Education Sub-Sector Investment Program, which along with administrative changes in the delivery of educational services and restructuring of the teachers payroll also led to some direct financing of schools through cash disbursements. While household responses are harder to interpret, data on household involvement suggests that parents are active in their children's education with high contributions, both in terms of expenditures and time. It is precisely this involvement that is studied below.

\subsection{Sampling}

The data are based on an Expenditure and Service Delivery Survey (ESDS) carried out in 182 schools in four provinces of the country during $2002 .{ }^{9}$ The choice of schools was based on a probability-proportionalto-size sampling scheme, where each of 35 districts in the four provinces was surveyed and schools were randomly chosen within districts with probability weights determined by enrollment in the school. Thus, every enrolled child in the district had an equal probability of being enrolled in a school that participated in the survey. ${ }^{10}$

For every school, a detailed questionnaire on budgetary receipts and expenditures was completed. In addition, as part of the expenditure tracking exercise, district and provincial educational offices associated with the surveyed schools were administered questionnaires detailing financial activity over the year (receipts and disbursements of cash and materials). This allows the creation of a matched data set that shows, for every level of the hierarchy, the cash (and materials) received, as well as the amount disbursed to the level below. Finally, at the level of the school, household questionnaires were completed for 20 randomly chosen pupils from Grade V and Grade VI (this is just before a jump in drop-outs at the end of Grade VII and thus fairly representative of all children in the school). The questionnaire included data on assets in the student's

\footnotetext{
${ }^{8}$ These levels are similar to Kenya, higher than Mozambique, but below those typically attained in other Southern African countries (see for example, UNESCO 2003). Nevertheless Zambia continues to outperform other African countries with similar per capita income levels (Das and others 2004).

${ }^{9}$ Lusaka, Northern, Copperbelt, and Eastern provinces were surveyed. These four provinces account for 58 percent of the total population in Zambia.

${ }^{10}$ Thus, although Zambia has high enrolment rates (above 90 percent), this survey still may not be appropriate for examining educational outcomes such as enrollment.
} 
household and is used to create a wealth index for students in the school (see Appendix 1 for details); this is referred to as the "School Wealth Index."

In addition to the school survey, household surveys were administered to 540 households in 35 villages. The choice of villages was designed to eliminate complications arising from school choice. Based on a geographical mapping of all schools, those that satisfied a "remoteness" criteria (defined as a distance of at least $5 \mathrm{kms}$ from the closest school) were chosen as starting points for villages in the household survey. From these schools, the closest (or second closest depending on a random number) village was chosen and 15 households were randomly chosen from households with at least one child of school-going age. These households were administered a questionnaire detailing, among other issues, child-level expenditure on education and asset holdings of the households. The paper refers to this data as the "remote sample" and the resulting wealth index of households as the "household wealth index."

\subsection{Description: Schools and Households}

Table 1 describes the schools in the sample disaggregated by rural, urban, and "remote" locations (the latter forms the basis for the household sample). Reflecting the overall decline in this sector, schools are under some stress. There are over 100 children for every functional classroom, student-teacher ratios are above the Zambian guideline of 40, and there are a large number of repeaters. Moreover, for almost every variable rural areas tend to do worse than their urban counterparts and this difference is magnified in the case of the "remote" school sample. For instance, asset holdings are one standard deviation lower in rural and 1.2 standard deviations lower in remote villages compared to urban areas.

The main school input, cash grants (recall that in-kind receipts were particularly low with schools receiving on average less than 0.05 textbooks, 0.012 desks, 0.001 chairs and 0.01 boxes of chalk per student), can be divided into two categories: rule-based grants received under a legislation that distributes $\$ 600$ (\$650 in the case of schools with Grades 8 and 9) to every school irrespective of enrollment and discretionary grants disbursed to schools at the discretion of the District Education Office. For all four provinces, rule-based flows are sent directly to the district and from there onwards to the schools (Figure 3). For discretionary grants, flows are directed to the province first in the case of centralized provinces (Northern and Eastern), but are sent directly to the district for decentralized provinces (Lusaka and Copperbelt). Thus, for both rule-based and discretionary grants, the district office has substantial power in deciding how to allocate the received funds.

Figure 4 explores the importance of different funding sources for educational expenditure based on the remote sample, disaggregated by schools that received high or low rule-based grants (with the cut-off at the median). Household expenditures (30 percent) and rule-based cash grants (20 percent) account for a large share of total spending on education. The other significant component is salaries for teachers (50 percent) ; ignoring this doubles the shares of both household expenditures and rule-based cash grants. Since households in the "remote" sample are significantly poorer, this represents a lower bound on the actual share of household expenditure in total funding. Hence, even in remote and poor areas, households represent an extremely important component of educational funding and it is likely that they have sufficient leeway to 
adjust for government subsidies received at the school level. In fact, in anticipation of the results below, household shares decline when cash grants increase, suggesting some substitution between the two.

\section{Results}

To answer the questions raised in the introduction above, the results are presented in three parts. The first studies the extent to which executed budgets reach their intended beneficiaries. The second then turns to the distributional impact of government subsidies - what percentage of disbursed cash grants were given to the poor rather than the rich? The last presents estimates on the extent of household substitution. Using these estimates the counterfactual distribution of educational expenditure in the absence of government subsidies is constructed and compared to the current distribution of such expenditures.

\subsection{Expenditure Tracking: What Funding Actually Reaches Schools?}

On average in Zambia K 28,000 per pupil enters the educational system at the level of the province (this does not include material flows or teacher remuneration), with approximately 30 percent of this earmarked for rule-based cash grants through the fixed-school grant of $\$ 600$ ( $\$ 650$ for schools with Grades 8 and 9), and 70 percent in the form of funding allocated at the discretion of provinces and districts. To study the percentage of funds disbursed to provinces/districts that actually reached schools, two different averages are presented. The per-student funding in each province provides an estimate of the percentage of funding that reaches schools. Since the rule-based component of funding is a per-school amount (rather than a per-student amount), per-school funding then shows "leakage" in the disbursement of such funds.

Table 2 (Columns 1, 2 and 3) show the funds available in the entire system, funds available at the province level, and funds available at the district level calculated from financial records at the provincial and district education offices. Column 4 then reports only the rule-based funds available at the district. Following the funding flow diagram (Figure 3), total funds available at the district are a combination of rule-based and discretionary funding. Since rule-based funding is allocated on a per-school basis, districts with a larger number of schools but the same total enrollment receive larger amounts and this is reflected in Column (2) with Copperbelt and Lusaka (which have larger average school sizes) consistently reporting less than Northern and Eastern.

Columns (5), (6) and (7) then report the total amount passed on to schools. To check for robustness, three different options are used to calculate this amount. Option 1 (Column 5) is a direct measurement of cash passed on from the district to the schools in the sample and is thus only for the sample of schools covered by the survey and for a six-month recall period. Option 2 (column (6)) is based on an examination of spending patterns at the district during the month of May 2002. Finally, option 3 (column 7) uses data collected at the school with a six-month recall period. The high correlation between all three measures provides some confidence in the reliability of the reported financial data. Further, although there is some variation in the amounts depending on the option used, Option 3 always lies between Options 1 and Option 2. One can thus use the amount calculated from Option 1 as the upper bound of school receipts and those calculated from 
Option 2 as the corresponding lower bounds. Finally, Column (8) and (9) shows the percentage of available funds disbursed to schools through rule-based and discretionary funds, respectively.

Option 1 (the upper bound) suggests that between 25 and 48 percent of total funding (between K 5,000 and K 13,600 per pupil) in the system is passed on to schools; Option 2 (the lower bound) suggests 11 to 33 percent (between $\mathrm{K} \mathrm{2,500}$ and $\mathrm{K}$ 8,000). Typically less than one-half the funding in the system reaches the school level; in Eastern and especially in Lusaka province, the share seems much lower. ${ }^{11}$ Moreover, the part of funding that is passed on from rule-based grants is orders of magnitude higher than that from discretionary grants. In all four provinces, at least 40 percent of the rule-based grants at the district level are passed on to schools and this proportion drops to below 20 percent for discretionary grants. In general, the amount that finally reaches schools is much less than the total amount available in the system and this decline is the sharpest in Eastern province (Figure 5).

Instead of per-student funding, Table 3a presents funding per school. Findings on the disbursement of rule-based components of funding are positive, with little evidence of leakage. More than 90 percent of schools receiving the funds allocated in every province (except Lusaka), with the remainder divided equally among those that received nothing and those that received less than the allocated amount. In both cases, explanations relating to delays in disbursement and measurement error rather than leakage in the delivery system are likely explanations.

Specifically, in the case of schools that have not received any cash (particularly the 28 percent in Lusaka), actual disbursement started shortly before the survey was carried out and one possibility is that schools that received no money were experiencing delays in disbursement (i.e., head teachers had not yet gone to the district headquarters to receive the check) rather than the money being diverted at a higher level of the administrative hierarchy. For the small number that report receiving less than the allotted amount (two schools each in Eastern and Northern province) the amounts reported are between $\$ 363$ and $\$ 500$ and these may reflect errors in reporting or recording rather than actual variation in the amounts disbursed. ${ }^{12}$ Thus, in the case of this fixed-grant allotment it would appear that the educational administration is fairly efficient and unbiased in the allocation of funding resources to schools. Given the very small numbers of schools that had not received this funding at the time of the survey, there does not seem to be evidence of systematic leakage of diversion of funds from the schools.

Once we turn to discretionary allocations, however, these positive results are completely altered with few schools receiving any such funds and large variations among schools, conditional on receipt. Table 3b shows the percentage of schools that received no funds by province - less than 30 percent receive any money at all from discretionary sources.

\footnotetext{
${ }^{11}$ Interestingly, decentralization appears to have reduced spending at the provincial level, but there is no evidence that increased funding to districts in decentralized provinces is passed on to schools. As a percentage of total funds in the system, schools in centralized provinces receive around 30 percent of total funds and this actually decreases to 25 percent in the case of decentralized provinces. Thus, in terms of funding it appears that decentralization has shifted spending from the province to the district, with no improvement in disbursements to schools. These results need to be interpreted with some caution, since the decentralized provinces were not randomly allocated (Copperbelt and Lusaka are very different from Northern and Eastern province in a number of ways).

${ }^{12}$ In four cases this was confirmed through a follow-up with the Ministry of Education after 2 months.
} 
Comparing the shares of discretionary grants in school funding with the average amounts of such grants received shows that rule-based grants account for a large proportion of funding shares (88 percent), but a much smaller proportion of average amounts (43 percent). ${ }^{13}$ This suggests that there are two distinct ways in which schools receive cash grants. Rule-based grants tend to reach every school, thus accounting for the large funding share of this component. Discretionary grants reach very few schools (low funding shares), but conditional on a school receiving such funds, average amounts are likely to be large (high funding amounts). Thus, discretionary allocations are orders of magnitude higher, ranging from six times (Copperbelt) to 30 times (Lusaka) their rule-based counterparts. However, these larger amounts do not imply that a greater share of funding received is passed on; in fact, less than 20 percent of all discretionary funds eventually reaches schools.

\subsection{What are the Distributional Implications of Government Subsidies?}

The structure of disbursements outlined above has direct implications for the targeting of government subsidies across schools. Since schools received rule-based grants according to the allocation rule, the impact on equity depends entirely on the relationship between school size and student wealth. If wealthier students attend bigger schools, rule-based grants will be progressive. ${ }^{14}$ Implicit in this formulation is the assumption that a large share of variation in student wealth is driven by differences across schools; if most variation is within schools, the relationship between size and average wealth will be weak. For discretionary grants there is no ex-ante result - if funds were distributed randomly, they should be distribution-neutral. Alternatively, if wealthier schools with greater bargaining power received more the distribution will be regressive. ${ }^{15}$

Table 4 examines the underlying source of variation in student wealth. For the full sample, most of the variation is driven by differences across schools. The importance of between school differences decreases for the rural and remote samples but remains fairly high, accounting for at least 50 percent of the total variation in wealth. Moreover, for all schools and for rural schools only, average student wealth is positively correlated with school size, with the wealth index increasing by one-tenth of a standard deviation for every 100 additional students (Figure 6). In the remote sample, this relationship is weaker with both the coefficient and the level of significance dropping substantially; at the 10 percent level of confident there is no difference in wealth across schools with different enrollments in remote schools. Consequently, we expect rule-based grants to be highly progressive for both the full and the rural sample, and to remain so, although at a weaker level, for the remote sample as well.

This is confirmed through concentration curves, constructed by ranking all students in schools according to the school wealth index and plotting the cumulative share of total grants received by each decile. Formally,

\footnotetext{
${ }^{13}$ As an example, consider three schools that receive $\$ 10$ each from Source 1 , but while schools 1 and 2 each receive $\$ 0$ from source 2 , school 3 receives $\$ 90$. In this case, source 1 accounts for 70 percent of the average share, but only 25 percent of the average amount.

14 The term "progressive" means that the poorest X percent of the population receive more than X percent of total government subsidies.

${ }^{15}$ In contrast to the literature on benefit incidence, therefore, our variation is driven not by differences in access to the service across the wealth quintile, but differences in receipts by children who are already enrolled in school. Thus, to the extent that the poor are less likely to be enrolled than the rich, we overestimate the progressive nature of any subsidy. How big a problem is this for primary school enrollment? Given the historically high enrollment in Zambia, differential access may not affect the estimates considerably; regression estimates on the probability of enrollment suggest that one standard deviation in the wealth of the household increases the probability of enrollment in primary school by only 2.8 percent.
} 
the share of wealth decile $J^{*}$ in a population of $N$ agents is defined as

$$
\frac{\sum_{i \in J^{*}} w_{s}}{\sum_{i \in N} w_{s}}
$$

so that the cumulative share is the sum of all population groups ranked below $J^{*}$ in the school wealth ranking.

Figure 7 shows the results of this exercise for three types of government subsidies — rule-based cash grants, discretionary cash grants and teacher remuneration. For all samples rule-based funds are progressive, with the poorest deciles receiving more than 10 percent of the share of total rule-based grants. ${ }^{16}$ The extent to which they are progressive depends on the sample - for the full sample, large rural-urban differences in wealth accentuate the progressive nature of such grants. For only rural schools differences are smaller.

Turning to discretionary funding, in the full sample they are (approximately) wealth neutral, so that an equal share of funding is received by poorer and richer students. In the rural sample, however, these funds are regressive with a large share accruing to richer students, although this relationship is not significant at the 10 percent level of confidence.

Finally, the remuneration of teachers is regressive for the remote and the full sample, and wealth neutral for the rural only sample. The regressive nature of teacher compensation is due to two effects. First, teachers in rural schools tend to have larger class sizes than their urban counterparts (the average class size in rural schools is 63 compared to 42 in urban areas) and this inequality is enhanced due to larger teaching loads for rural teachers (by teaching multiple classes). Second, rural schools also have a larger number of traineeteachers (this was a scheme to provide teaching staff in rural areas whereby trainees would be posted to schools for one year) with lower salaries than their regular counterparts. Thus, rural teachers both tend to have more students and are paid less, on average. Given that rural schools are also poorer, the share of teacher funding that accrues to poorer students is smaller.

Thus, government subsidies given through rule-based grants were highly progressive due to the combination of a simple rule and the inverse relationship between student wealth and school enrollment. This provides a partial answer to the motivating questions in the introduction: resources allocated by the central government reach their intended beneficiaries if programs are well designed. Moreover, in the specific country context, sufficient across-school variation in the student population does allow for targeting at the school to be used as a feasible alternative for household subsidies. To complete the analysis, the next section turns to household responses - once such responses are incorporated, what is the impact of rule-based grants on total educational expenditure? ${ }^{17}$

\footnotetext{
${ }^{16}$ The results use the amount actually received by the school at the time of the survey.

${ }^{17}$ The focus on rule-based instead of discretionary grants follows from the dynamic implications of the model. Since rulebased grants were arguably anticipated in the previous period, household adjustments will already have taken place. In contrast, discretionary grants were, by their very nature, unexpected. Households would be unable to respond in the current period but future periods would see a downward adjustment of household expenditures for those that received discretionary grants during the current year. To abstract from these dynamic aspects, the paper focuses on current year responses for the anticipated (rule-based) grant only. The estimation procedure for household response elasiticities draws from Das and others (2004).
} 


\subsection{How do Households Respond to Rule-Based Grants?}

To study household responses, response elasticities to cash grants are estimated and these elasticities are then be used to determine a "counterfactual" distribution of private expenditures - the distribution of expenditures that would have ensued if government cash grants had not been available. The comparison of this counterfactual to the current distribution shows to what extent these cash grants were successful in reducing inequalities in overall expenditures.

To estimate household responses to rule-based cash grants, consider the following system:

$$
\begin{aligned}
\ln z_{i j s} & =\alpha+\beta_{1} \ln w_{s}+\beta_{2} \text { Assets }_{i}+\beta_{4} X_{i}+\mu_{s}+\varepsilon_{i j} \\
z_{i j s} & =\left\{\begin{array}{c}
z_{i j s}^{*} \text { if } z_{i j s}^{*} \geq 0 \\
0 \text { if } z_{i j s}^{*}<0
\end{array}\right\} \\
\ln w_{s} & =\gamma+\gamma_{1} X_{i}+\gamma_{2} \theta_{s}+\eta_{s}
\end{aligned}
$$

where $z_{i j s}$ is $(\log )$ spending on child $i$ in household $j$ and school $s ; w_{s}$ are $(\log )$ rule-based grants received in school $s$, Assets $_{i}$ is the household wealth index (from the household survey), and $X_{i}$ are additional controls including gender and age of the child, province dummies, and mean school and village-level wealth. Finally $\mu_{s}$ and $\varepsilon_{i j}$ are school and child-household specific error terms.

There are two important observations. First, $z_{i j s}$ is a censored variable - we observe positive values of spending for children who are enrolled, but zero values for those who are not enrolled (but are eligible). Hence a Tobit specification is used, and estimates from a random-effects Tobit model at the village level are presented as a robustness check. Second, $w_{s}=K /$ enrollment ${ }_{s}$, where $K$ is the legislated amount. There is thus a potential selection problem given by Equation (12), so that $\widehat{\beta_{1}}$ is inconsistent if $\operatorname{cov}\left(\eta_{s}, \mu_{s}\right) \neq 0$. Such a problem may arise, for instance, if households in rich villages send their children to school but also spend more on education. The coefficient $\widehat{\beta_{1}}$ would then capture the differences in underlying wealth rather than a causal response to rule-based grants. To some extent, such wealth differences are controlled for by including three different wealth indicators in the regression; the household wealth index, the average wealth index for the village and the school wealth index. Nevertheless, there may be other omitted variables in Equation (10) that lead to the inconsistent estimation of response elasticities.

To address this issue, the choice of sample is important. By restricting the sample of villages to only those where there was no school choice, the extent of the selection problem is reduced considerably. This strategy has been used previously by Case and Deaton (1999) and Urquiola (2001) in their studies of schooling inputs and cognitive achievement. However, the parental choice of sending children to school could still lead to differences in enrollment that are correlated to the error term. The paper thus explicitly checks that the "remote" school strategy provides exogenous variation in cash grants across schools.

Using the methodology proposed by Blundell and Smith (1986), the weak exogeneity of $\ln w_{s}$ is tested. The exclusion restriction for this test is satisfied if there is a variable, $\theta_{s}$, that is correlated with $\ln w_{s}$, but not $z_{i j s}$; the size of the eligible cohort in the catchment area and the distance to school are used on the 
assumption that these variables are correlated to enrollment, but not expenditure on the child conditional on enrollment. The test rejects exogeneity if the coefficient on the residual obtained from Equation (12) is significant in Equation (10) above. The inability to reject the null hypothesis establishes the exogeneity of $\ln w_{s}$ under the assumption that the size of the eligible cohort and the distance from the school are exogenous to household spending on children's' schooling.

The results from this estimation are presented in Table 5a and 5b. Columns (1) and (2) show estimated coefficients from the Tobit specification and (3) and (4) from the analogous Tobit with random effects. Table $5 \mathrm{~b}$ then interprets these coefficients as the probability of censoring and the marginal impact at the mean conditional on the dependant variable not being censored. The results show that the estimated elasticity of substitution for rule-based grants is always negative and significant, ranging from -0.49 to -0.52 . Finally, the test of exogeneity cannot be rejected (Column 4, Table 5a) with the residual from the first stage not significant at the 15 percent level of confidence, suggesting that the estimated relationship between $z_{i j s}$ and $w_{s}$ can be given a causal interpretation.

How plausible are these results in the context of education in low-income countries? An important observation is that Zambia differs considerably from other countries regarding the level of parental involvement in children's education. Among the households in this sample, 64 percent of respondents had attended the last Annual General Meeting in the school, 58 percent had voted in the last Parent Teacher Association election and 60 percent reported home visits from teachers in the school to discuss their child's performance. Although it would be useful to benchmark these numbers with comparable statistics from other countries, it is likely that the households in this sample were aware of both the resources that were available in the school, as well as the educational materials that were purchased with the money. In this context of high participation by parents, the fact that cash grants led to the crowding-out of household educational expenditures is not particularly surprising.

\subsection{Impact on Equity of Rule-Based Grants}

If the relationship in Equation (10) is causal, the counterfactual distribution in the absence of rulebased grants, $z_{i j s}^{\text {counter }}$, can be arrived at by predicting expenditures when $w_{s}=0$. A slightly different specification is required for this exercise. Specifically, since Equation (10) uses log spending and log grants, the counterfactual distribution cannot be determined based on this specification. ${ }^{18}$ Since the estimated coefficient on censoring as a result of the rule-based grants are small (suggesting that the effects of such grants on school participation were small), an analogous specification in levels is estimated, using $w_{s}$ and interactions between household assets and $w_{s}$ (to allow for differential responses for different wealth levels) as regressors. This equation is given by

$$
z_{i j s}=\alpha+\beta_{1} w_{s}+\beta_{2} \text { Assets }_{i}+\beta_{3}\left(\text { Assets }_{i} \times w_{s}\right)+\beta_{4} X_{i}+\mu_{s}+\varepsilon_{i j}
$$

To determine the counterfactual distribution, there are two options. One is to predict $\widehat{z_{i j s}}$ with $w_{s}=0$ and add an error drawn from a distribution with moments determined from the distribution of residuals in

\footnotetext{
${ }^{18}$ Technically, the support of the distribution changes with the $\log$ specification since $G_{s} \in[0, \infty]$ but $\log G_{s} \in[-\infty, \infty]$.
} 
Equation (13) above. Given the simple structure of the counterfactual, a second option is to determine this distribution as

$$
\left(\widehat{z_{i j s}} \mid w_{s}=0\right)=z_{i j s}-\widehat{\beta_{1}} w_{s}-\widehat{\beta_{3}}\left(\text { Assets }_{i} \times w_{s}\right) .
$$

To the extent that there are household fixed-effects such as $\mu_{s}$ (uncorrelated with $w_{s}$ ) the second strategy is an attractive alternative; the disadvantage is that the counterfactual $z_{i j s}$ is observed for a single draw of the error term $\varepsilon_{i j}$. While there are no statistical means of determining the optimal strategy, it is reasonable to assume that with cross-sectional data the second option presents a better alternative.

Once $\left(\widehat{z_{i j s}} \mid w_{s}=0\right)$, referred to as the "counterfactual expenditure" is computed, three different concentration curves can be constructed: (a) the concentration curve for current household educational expenditures based on shares of spending by different population groups $J^{*}$ defined as $\frac{\sum_{i \in J^{*}} z_{i j s}}{\sum_{i \in N} z_{i j s}}$; (b) the concentration curve for current total educational expenditures with the share of spending by group $J^{*}$ defined as $\frac{\sum_{i \in J^{*}}\left(z_{i j s}+w_{s}\right)}{\sum_{i \in N}\left(z_{i j s}+w_{s}\right)}$; and (c) the concentration curve for counterfactual household educational expenditure with the share of spending by group $J^{*} \equiv \frac{\sum_{i \in J^{*}}\left(\widehat{z_{i j s}} \mid w_{s}=0\right)}{\sum_{i \in N}\left(\widetilde{z_{i j s}} \mid w_{s}=0\right)}$.

Figure 8 presents the results from this exercise. The counterfactual distribution of household expenditures dominates that of current household expenditures with the share of every wealth quintile closer to the $45^{0}$ line in the absence of cash grants from the government. This is consistent with the results of the estimation given by Equation (13) above whereby households in upper wealth deciles responded less to the cash grants than those in the lower deciles. ${ }^{19}$ This worsening of inequalities in educational expenditures is somewhat attenuated when we consider total educational expenditures (the sum of household expenditures and cash grants), but the distribution of total expenditures continues to be dominated by that of counterfactual expenditures (although the difference is not significant). Hence, rule-based cash grants, which were highly successful in terms of the efficiency of distribution as well as targeting to the poor had no impact on reducing inequalities in overall educational expenditures in the Zambian school system.

\section{Discussion and Conclusion}

Rule-based cash grants in Zambia were advocated through a program of educational reform and the simplicity of the rule made such grants an attractive proposition - every school would receive a fixed amount of cash irrespective of enrollment. These grants were also very large. After accounting for household responses, they represented 60 percent of educational expenditures by the household for the lowest wealth deciles and 45 percent for the top wealth decile. The simplicity of the rule ensured that the grants reached their intended recipients, and indeed over 90 percent of schools in our survey received the grants in the earmarked fashion. Moreover, due to an inverse relationship between school enrollment and student wealth, the grants were also highly progressive, with the lowest decile receiving 16 percent of the total grants and the median 70 percent. On the face of it then, these grants were very successful in both their delivery and targeting aspects.

This paper argues that such a view should be tempered by the specific objective of the social planner. These grants undoubtedly resulted in a larger share of resources reaching the poor. Thus, if the primary

\footnotetext{
${ }^{19}$ Results are available from the author.
} 
objective of the social planner was to redistribute resources to the poor, the grants were successful -incomes of the poor increased relative to those of the non-poor as a result of the grants. If however, the objective of the social planner was to increase equity in overall educational expenditure, these grants were less successful. Cash grants had the unfortunate repercussion of crowding out household educational expenditures with the poor responding more than the rich. Consequently, the impact of these grants on overall educational expenditure was negligible, with the share of the poorest decile remaining more or less static, irrespective of the grant amount .

In terms of the theoretical structure presented earlier, this suggests that schools could only spend the cash grant on inputs that were highly substitutable with household provision. ${ }^{20}$ This is borne out anecdotally. For instance, two inputs that have impacts on schooling performance are teachers (see for instance, Hanushek 1971) and infrastructure (Glewwe and Jacoby 1994). However, in the specific country context, both these inputs could not be provided by the school. As an example, despite the consistent complaint of understaffing by head teachers, there were only two instances in which a school had tried to hire teachers on its own. In both cases, the teachers were far less educated and trained than their government counterparts, leading to considerable dissatisfaction among parents.

An important caveat to these results arises from the nature of the sample. While the choice of the remote sample decreases the complexity of the estimation problem, it comes at a cost. This remote sample is very different from the rest of the country with much lower average wealth and lower inequality. It is likely that responses to the grants in other parts of the country were different from those estimated here, and a more data-intensive exercise using household expenditures before and after the grants would yield response elasticities other than those obtained for the remote sample. In the absence of a panel data structure, the specific sampling strategy allowed us to deal with problems arising from school selection. Clearly this is an issue that can be better addressed in studies with access to both pre and post-intervention data of household expenditures linked to school inputs.

The equitable distribution of educational expenditure, though an attractive theoretical goal, requires careful implementation on the ground. For subsidies to reach their intended recipients, the results suggest that clearly defined rule-based allocations are more likely to be successful. However, even when subsidies are efficiently allocated and progressive, how they affect the overall distribution of expenditure depends on household responses. In the context of education, providing inputs that can be purchased in a competitive market (such as textbooks) crowds out household expenditure and may not impact on educational outcomes, except as an income subsidy. On the other hand, providing inputs that are characterized by systematic market failures (such as monopoly provision or externalities) or that are complements to household provision will have larger effects, both on equity and educational outcomes.

\footnotetext{
${ }^{20}$ Of course, another problem with the rule-based grants as they currently stand are the dynamic incentives for schools, whereby schools are rewarded with increased per-pupil funding if they decrease enrollment.
} 


\section{Appendix 1: Description of Asset Index}

Item Response Theory (IRT) methods are used to generate the asset indices. The IRT asset index performs similarly to the principal components methods discussed by Filmer and Pritchett (1999). Comparisons based on simulations carried out by the author and others show that the correlation between the IRT index and the principal components method is more than 0.98 in the countries for which Demographic and Health Status data is available. The main advantage of using the IRT methods is that, in addition to providing the index, it also provides standard errors of the index at each wealth level. This then is useful in evaluating the accuracy of the index at different levels of wealth. The main assumption in IRT is that there is a unique dimension (wealth) that maps to the probability of owning an asset.

Two asset indices were created for this paper. The first is based on the assets of students in the school surveyed. This is used (for instance) in the construction of concentration curves for the full sample. The second asset index is created for the household sample using the survey of households. Table A.1 shows the components used for the asset index at the household level. Table A.2 shows components used for the asset index at the school level. For the school sample, fewer assets are available for the exercise. On the whole, the wealth index is reasonably accurate in the range of the sample: Copperbelt comes out as the richest province, followed by Lusaka, Northern, and Eastern. Further, the index was much higher for children going to private schools. Figure A.1 for instance, presents the 95 percent confidence interval of the index for the household sample. 
The word processed describes informally reproduced works that may not be commonly available in libraries.

\section{References}

Ablo, Emmanuel, and Ritva Reinikka. 2000. "Do Budgets Really Matter: Evidence from Public Spending on Education and Health in Uganda." Policy Research Working Paper 1926. World Bank, Washington, D.C.

Acemoglu, Daron, Simon Johnson, and James Robinson. 2001. "The Colonial Origins of Comparative Development: An Empirical Investigation." American Economic Review 91: 1369-1401.

Banerjee, Abhijit. 2003. "Educational Policy and the Economics of the Family." Massachusetts Institute of Technology. Processed.

Bardhan, Pranab K., and Dilip Mookherjee. 2000. "Capture and Governance at Local and National Levels." American Economic Review 90 (2): 135-39

Blundell, Richard W., and Richard Smith. 1986. "An Exogeneity Test for a Simultaneous Equation Tobit Model with an Application to Labor Supply." Econometrica 54: 679-85.

Brown, Peter. 2003. "Parental Education \& Child Learning: Human Capital Investments in Time and Money." Michigan University. Processed.

Burnside, Craig, and David Dollar. 2000. "Aid, Policies and Growth." American Economic Review 90 (4): $847-68$.

Case, Anne, and Angus Deaton. 1999. "School inputs and educational outcomes in South Africa." Quarterly Journal of Economics 114 (3): F1047-F84.

Cox, Donald, and Emmanuel Jimemez. 1995. "Public Income Redistribution in the Philippines." In Dominique Van de Walle and Kimberly Nead, eds., Public Spending and the Poor: Theory and Evidence. Baltimore: Johns Hopkins University Press for the World Bank.

Das, Jishnu, Stefan Dercon, James Habyarimana, and Pramila Krishnan. 2002. "Rules vs. Discretion: Public and Private Funding in Zambian Education." Development Research Group, World Bank, Washington, D.C. Processed.

Das, Jishnu, Stefan Dercon, James Habyarimana, and Pramila Krishnan. 2004. "When Do School Inputs Improve Test Scores?" Policy Research Working Paper \#3217. The World Bank. Washington D.C.

Djankov, Simeon, F. López-de-Silanes, Rafael La Porta and Andrei Shleifer. 2002. "The Regulation of Entry." Quarterly Journal of Economics 117(1): 1-37.

Easterly, William, Ross Levine, and David Roodman. 2003. "New Data, New Doubts: A Comment on Burnside and Dollar's 'Aid, Policies and Growth." Working Paper 9846. National Bureau of Economics Research, Cambridge, Mass. 
Epple, Dennis, R. Filimon, and T. Romer. 1984. "Equilibrium among Local Jurisdictions: Toward an Integrated Treatment of Voting and Residential Choice." Journal of Public Economics 17: 281-308.

Fernandez, Raquel, and Richard Rogerson. 1996. "Income Distribution, Communities and the Quality of Public Education." Quarterly Journal of Economics 111 (1): 135-64

Filmer, Deon, and Lant Pritchett. 1999. "The Effect of Household Wealth on Educational Attainment: Evidence from 35 Countries." Population and Development Review 25(1): 85-120.

Frye, Timothy, and Andrei Shleifer. 1997. "The Invisible Hand and the Grabbing Hand." American Economic Review 87 (2): 354-58.

Galor, Oded, and Joseph Zeira. 1993. "Income Distribution and Macroeconomics." Review of Economic Studies (60) 1: 93-124.

Glewwe, Paul, and Hanan Jacoby. 1994. "Student Achievement and Schooling Choice in Low-Income Countries: Evidence from Ghana." Journal of Human Resources 29 (3): 843-64.

Hammer, Jeffrey, Ijaz Nabi, and J. A. Cercone. 1995. "Distributional Effects of Social Sector Expenditures in Malaysia, 1974 to 1989." In D. van de Walle and K. Nead, eds., Public Spending and the Poor: Theory and Evidence. Baltimore: Johns Hopkins University Press for the World Bank.

Hanushek, Eric A. 1971. "Teacher characteristics and gains in student achievement: Estimation using micro data." American Economic Review 60 (2): 280-88

Hoxby, Caroline. 1995. "Is There an Equity-Efficiency Trade-off in School Finance? Tiebout and a Theory of the Local Public Goods Producer." Working Paper 5265. National Bureau of Economic Research, Cambridge, Mass.

Jacoby, Hanan G. 2002. "Is There an Intrahousehold 'Flypaper Effect'? Evidence from a School Feeding Programme." The Economic Journal 112 (Jan): 196-221.

Khwaja, Asim. 2002. "Can Good Projects Succeed in Bad Communities? Collective Action in the Himalayas." Harvard University. Processed.

Moffit, Robert. 1992. "Incentive Effects of the U.S. Welfare System: A Review." Journal of Economic Literature 30: 1-60.

Ravallion, Martin, and Gaurav Datt. 1995. "Is Targeting Through a Work Requirement Efficient? Some Evidence for Rural India." In Dominique Van de Walle and Kimberly Nead, eds., Public Spending and the Poor: Theory and Evidence. Baltimore: Johns Hopkins University Press for the World Bank.

Reinikka, Ritva, and Jakob Svensson. 2002. "Explaining Leakage of Public Funds." Discussion Paper 3227. Center for Economic Policy Research, London, United Kingdom.

Rosenzweig, Mark, and Kenneth Wolpin. 1994. "Parental and Public Transfers to Young Women and Their Children." American Economic Review 84: 1195-1212. 
Transparency International. 2002. "Corruption Perceptions Index." [Retrieved on January 27, 2004 from http://www.transparency.org/cpi/2002/cpi2002.en.html.]

UNESCO. Various years. "Edstats." [Retrieved on September 2, 2003, from http://devdata.worldbank.org/edstats/about_data.asp]

Urquiola, Miguel. 2001. "Identifying class size effects in developing countries: Evidence from rural schools in Bolivia." Policy Research Working Paper 2711. World Bank, Washington, D.C.

Van de Walle, Dominique. 1992. "The Distribution of the Benefits from Social Services in Indonesia, 197887." Policy Research Working Paper 871. World Bank, Country Economic Department, Washington, D.C.

Van de Walle, Dominique, and Kimberly Nead., eds., 1995. Public Spending and the Poor: Theory and Evidence. Baltimore: Johns Hopkins University Press for the World Bank.

Van de Walle, Dominique. 1998. "Assessing the Welfare Impacts of Public Spending." World Development 26(March): 365-79.

Van de Walle, Dominique. 2003. "Behavioral Incidence Analysis of Public Spending and Social Programs." In F. Bourguignon and L. Pereira de Silva, eds., The Impact of Economic Policies on Poverty and Income Distribution: Evaluation Techniques and Tools. Washington, D.C.: A copublication of the World Bank and Oxford University Press. 


\section{Figures}

Figure 1: Production Functions in Household Optimization

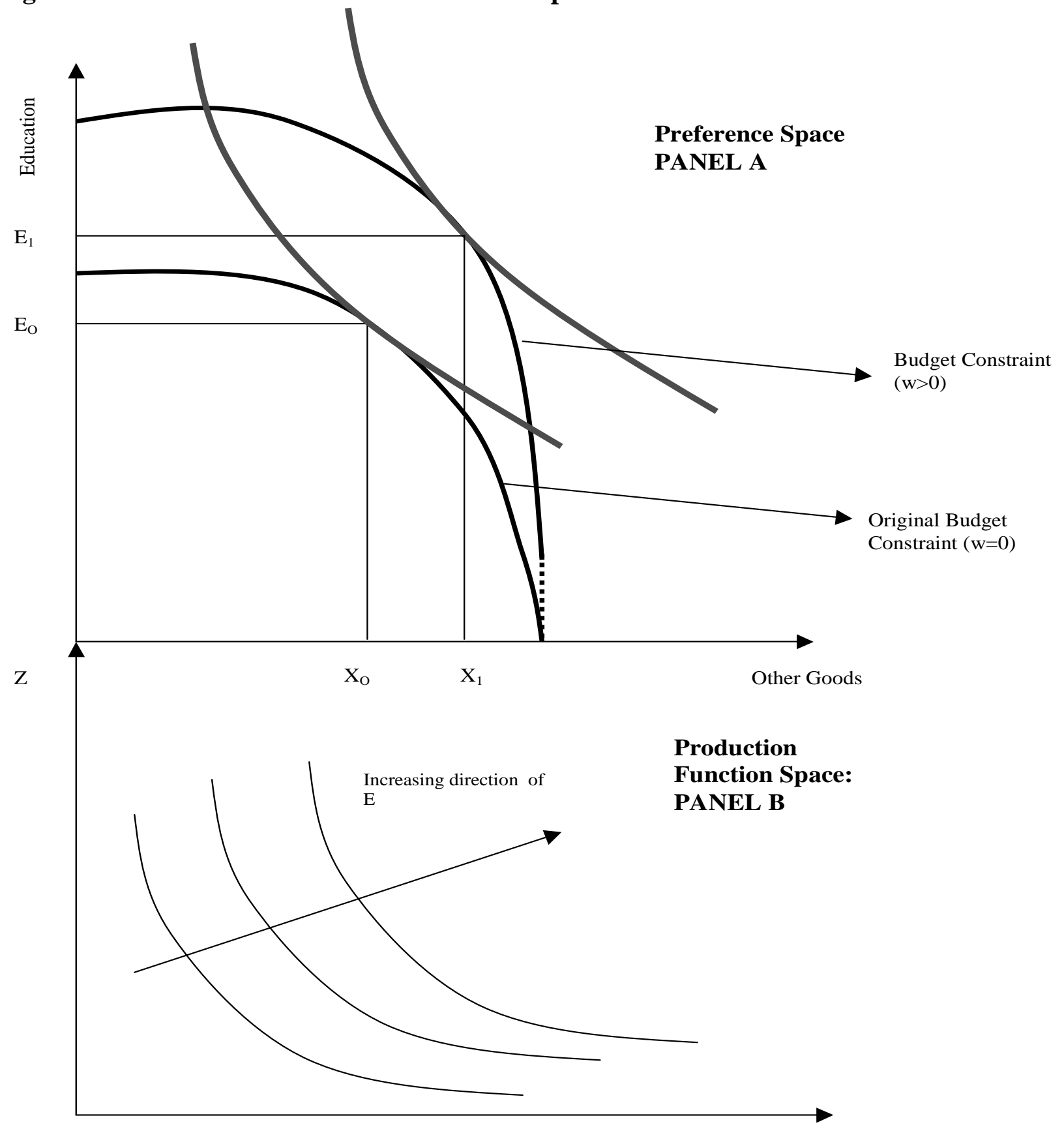




\section{Figure 2: Concentration Curves Based on CES Production Functions}

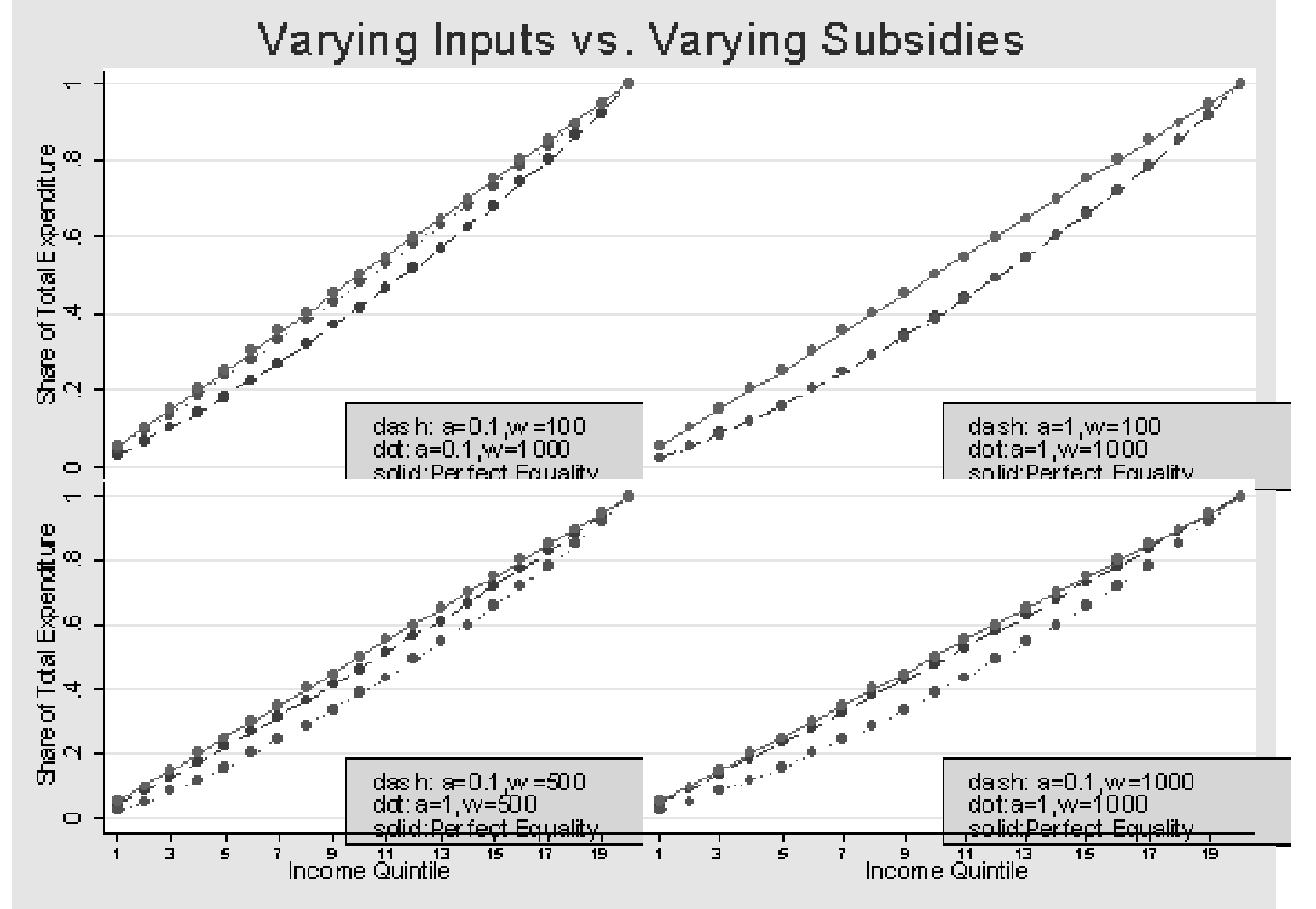

Note: This figure shows how the distribution of overall expenditure is affected by subsidies at the school level for production functions with different elasticity of substitution. Every point on a curve represents the share of total expenditure that is spent by the corresponding income decile and the diagonal is the line of perfect equality where every quintile spends exactly 5 percent of the total. The simulations are based on normally distributed wealth with mean 5,000 and standard deviation 1,000, so that $\mathrm{w}=$ 1,000 corresponds to 20 percent of income. The alphabet "a" represents the elasticity of substitution, so that higher values represent higher substitutability between school and household inputs. 


\section{Figure 3: Flow of Funds through the Administrative Hierarchy (Zambia)}

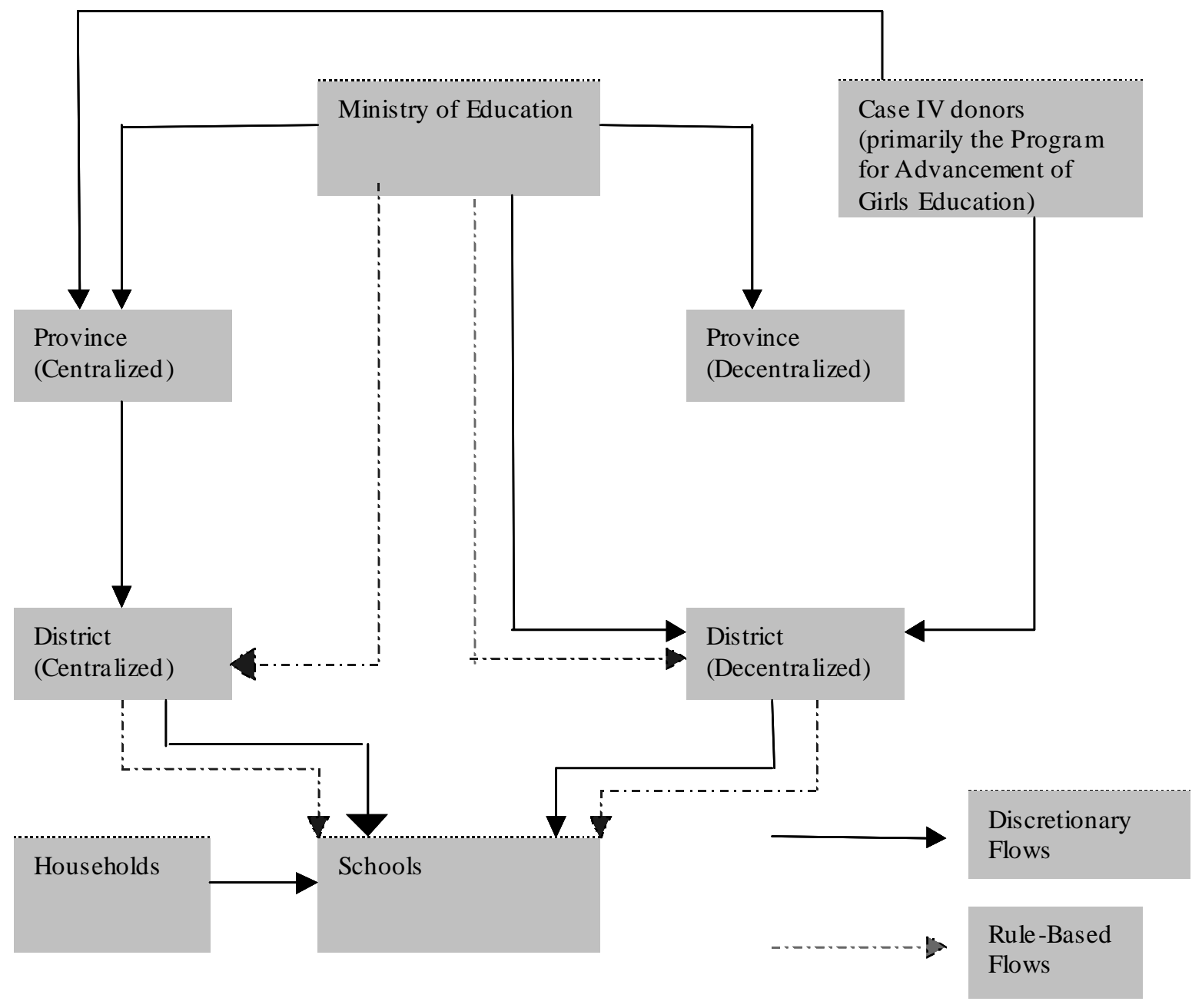

Note: This stylized diagram shows how funds flow through the administrative hierarchy. Funds are divided into two categoriesdiscretionary grants and rule-based grants. In both centralized and decentralized provinces, rule-based grants are sent directly to the district and from there onward to schools. Discretionary grants are sent to provinces first in centralized provinces, and to districts directly in decentralized provinces. 
Figure 4: Household Expenditures and School Funding

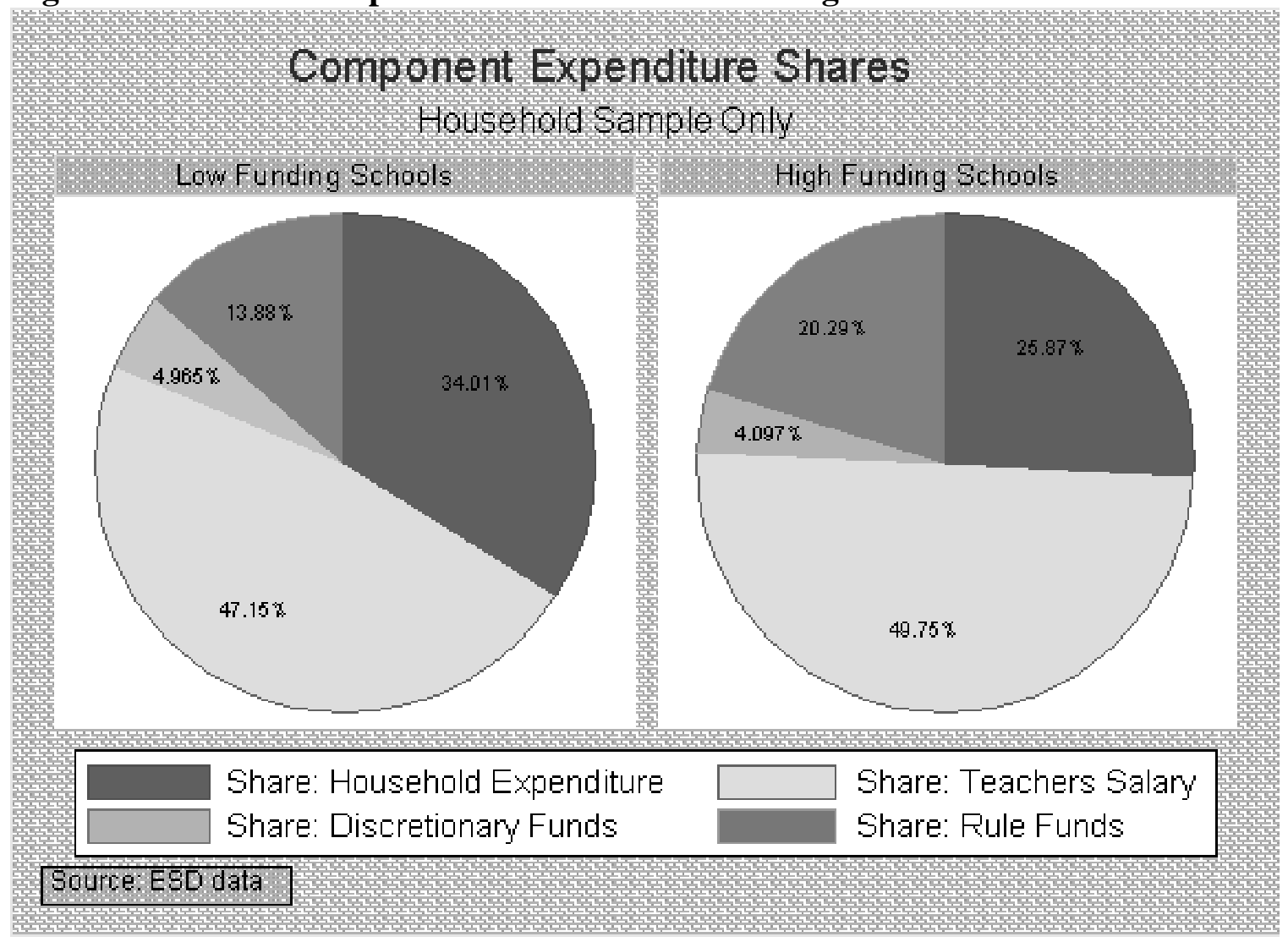

Note: The pie chart shows how educational inputs are funded in schools that received high/low anticipated funds. The shares are computed as the average of shares across schools. Teacher's Salary is computed as salary divided by the number of students in the teacher's class. This is computed for a sample of teachers who were interviewed if they were either currently teaching Grade VI or Grade V students, or had taught Grade V students in the previous year. The particular sample was chosen to ensure that teacher characteristics could be matched to students who were tested in both years. Salaries will therefore be biased if there is selection of teachers into different grade levels. Household expenditure is based on a one-year recall question of household educational expenditure for every child on various items including textbooks, school supplies, and uniforms. Discretionary funds are unanticipated by households. 


\section{Figure 5: Funding Disbursement in Zambia}

Funding Disbursement: Decentralized Provinces

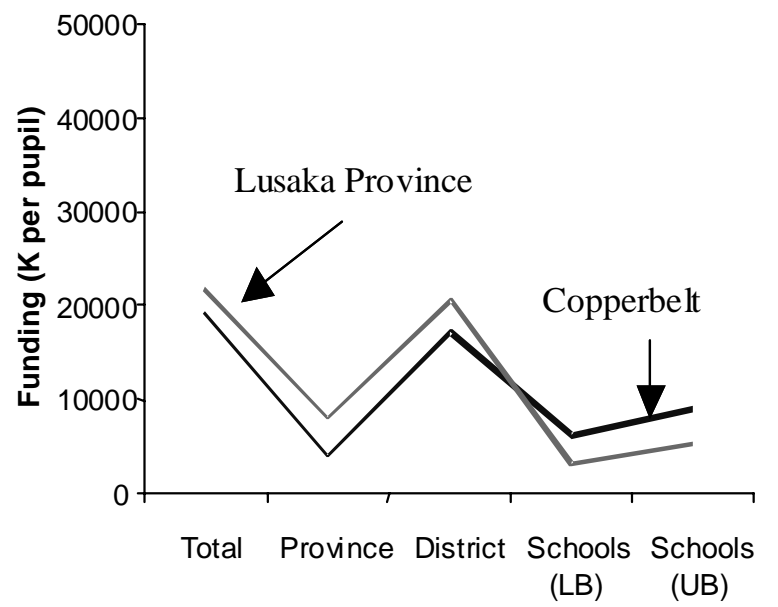

Funds at Each Administrative Level
Funding Disbursement: Centralized Provinces

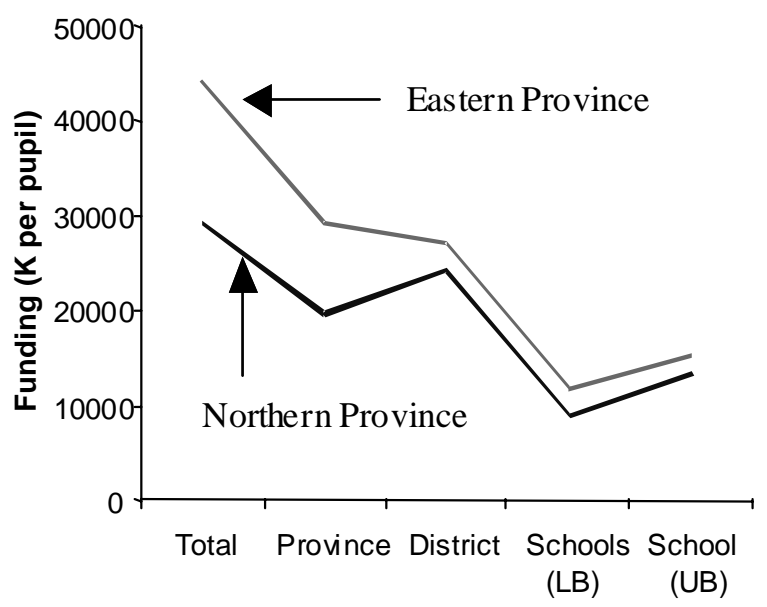

Funds at Each Administrative Level

Note: This figure shows how funds flow through each level of the administrative hierarchy. Total funds are the sum of funds that reach either the province or the district. (LB) and (UB) correspond to the upper bound and lower bound of funds that eventually reached schools. In decentralized provinces more funds are available at the district compared to the province due to the direct funding of districts from the Ministry of Education. Per-pupil funding is higher in the centralized provinces due to the larger number of small schools, combined with the structure of the rule-based allocation. 


\section{Figure 6: The Relationship between Wealth and Enrollment}

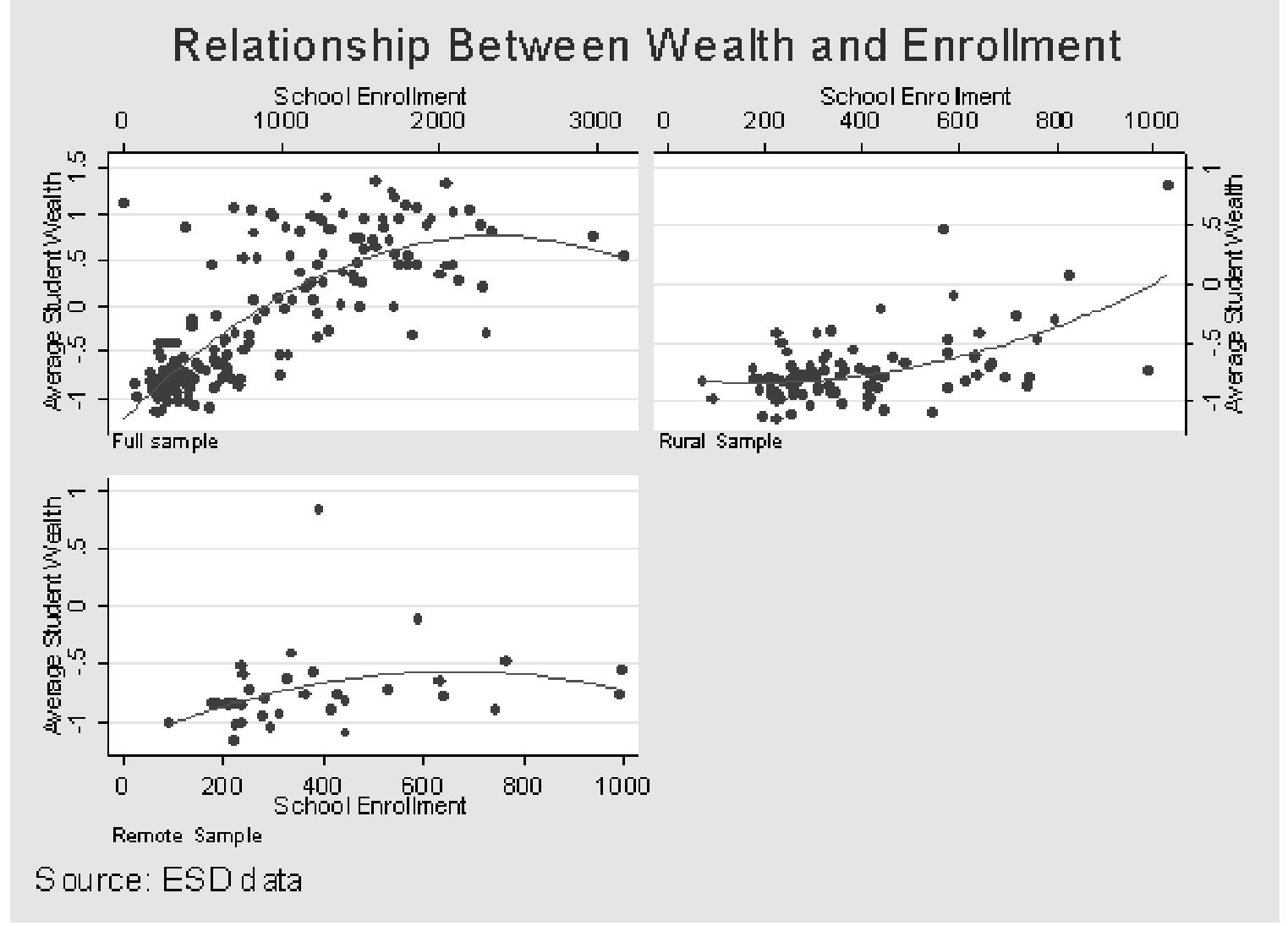

Note: This graph shows the relationship between student wealth and school enrollment. Student wealth is based on a survey of household assets administered to 20 randomly selected students from Grade V and VI; school enrollment is based on school census data from the Ministry of Education and the Expenditure and Service Delivery Survey data. For details on the construction of the asset index, see Appendix 1. For each sample, a quadratic relationship is fitted to the scatter of enrollment and wealth. Linear regression results suggest that student wealth is highly correlated with enrollment in the full sample and the rural sample, but not in the remote sample. 
Figure 7: Concentration Curves for School Funding

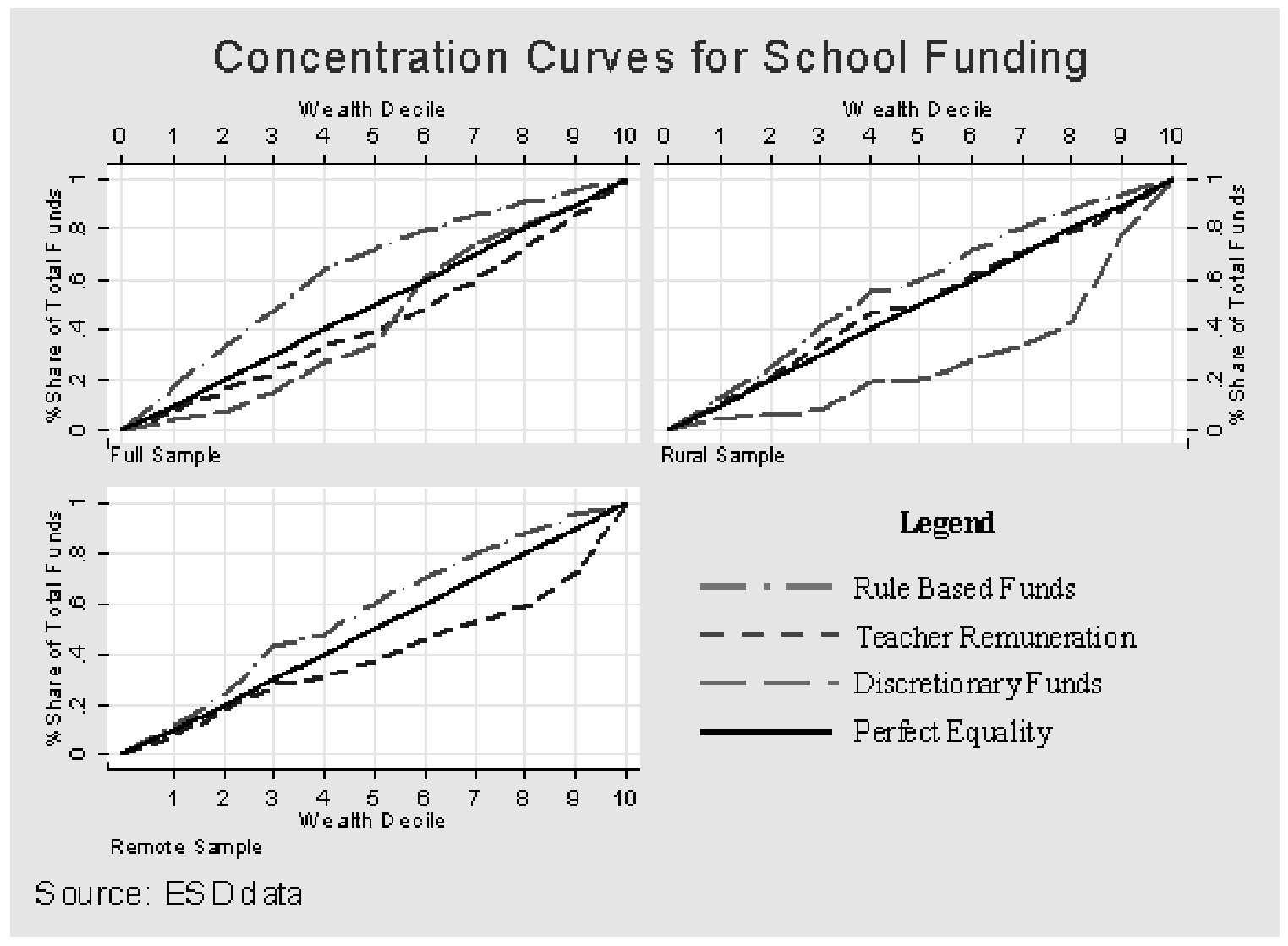

Note: This figure shows concentration curves (the share of total expenditure for every wealth decile) for government subsidies. The wealth decile is computed using Item Response Theory, details are in Appendix 1. Rule-based and discretionary funds are calculated as the ratio of funds received at the school level to school enrollment; teacher remuneration is based on a survey of all teachers of Grade V and VI in the surveyed schools and includes salary and allowances received in the previous month. This amount is then divided by the total number of children taught by the teacher. To the extent that these teachers are not representative of all teachers (for instance, better and higher paid teachers may be assigned to higher classes) the averages may not be correct. The direction of bias cannot be determined. 
Figure 8: Inequality in Total Educational Expenditure

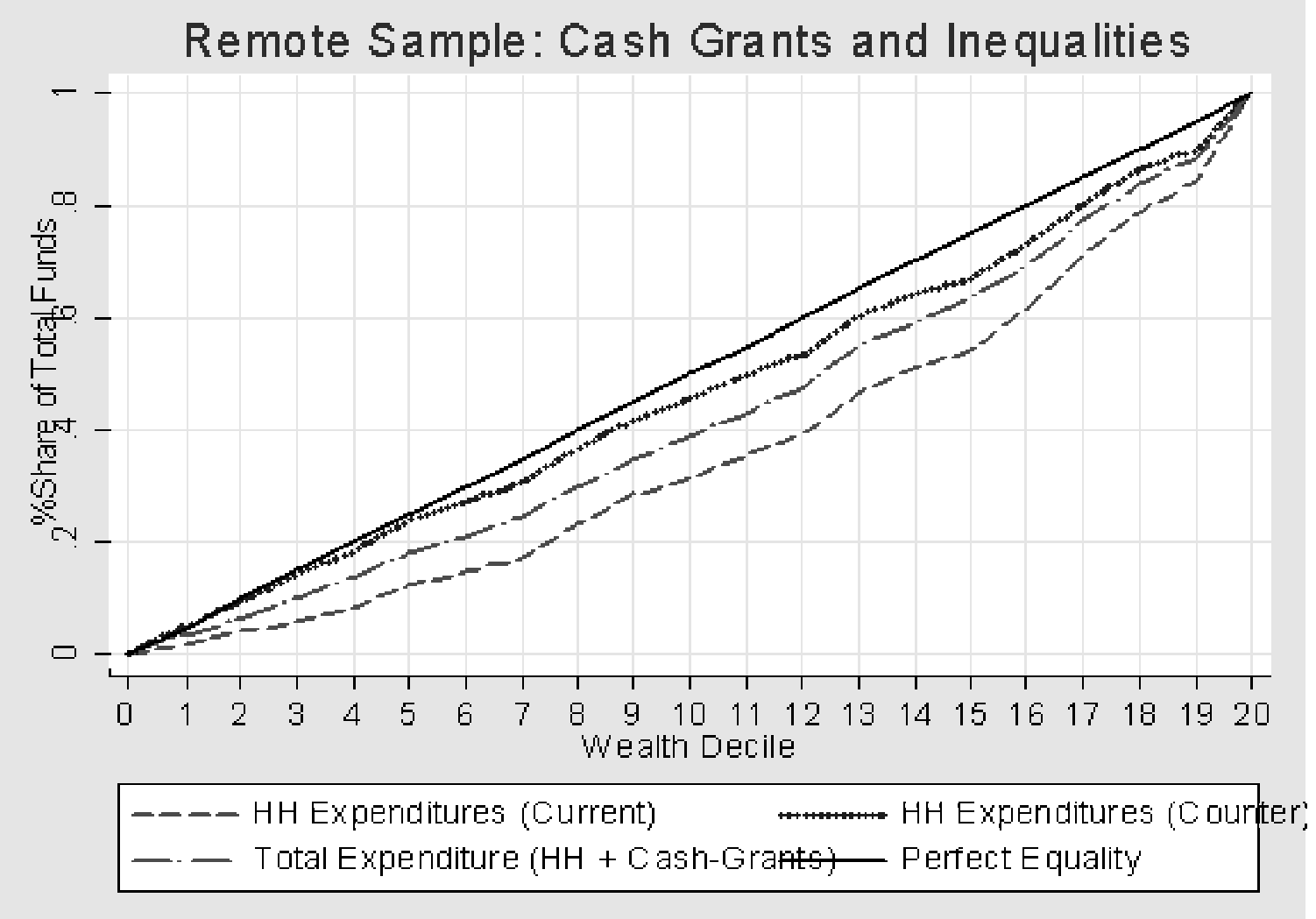

Note: This figure shows concentration curves for counterfactual and observed distributions of educational expenditure. The dashed line (HH Expenditures (Current)) corresponds to the observed distribution of expenditures on children's education. The dotted line (HH Expenditures (counter)) shows the distribution that would have obtained if the rule-based grants were zero. The dashed-dotted line (Total Expenditure ( $\mathrm{HH}+$ Funds)) shows the total observed expenditure including rule-based funds and the solid line shows rule-based funds. The graph is based on an underlying OLS estimation of expenditure that includes the rulebased funds, household wealth index, an interaction term between rule-based funds and the household wealth index, the age and gender of the child, and mean village and school assets. The sample is restricted only to those children who are currently attending school with the assumption that the size of the grant does not change enrollment status.

Source: Author's calculations based on Expenditure and Service Delivery Survey Data. 


\section{Figure A.1: Asset Index Standard Errors}

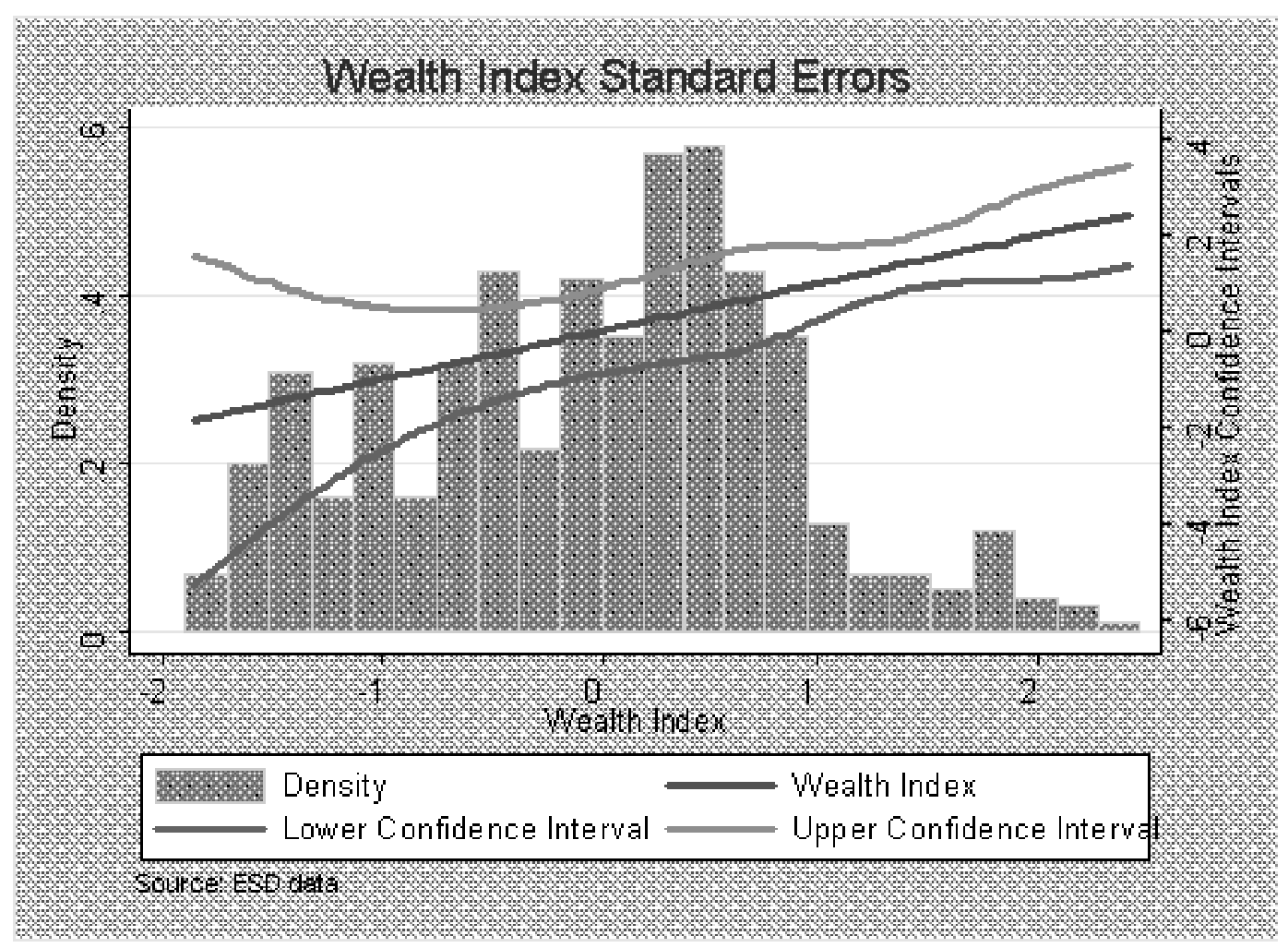

Note: This figure shows the histogram of the household wealth index and the 90 percent confidence intervals from the item response methodology detailed in Appendix 1. The confidence intervals are on the right axis and the histogram density on the left axis. 


\section{Tables}

Table 1: Descriptive Statistics: School Enrollment and Staffing

\begin{tabular}{|c|c|c|c|c|}
\hline Category & Variable & Urban & Rural & $\begin{array}{c}\text { "Remote" schools } \\
\text { (HH Sample) }\end{array}$ \\
\hline \multirow{3}{*}{ Basic indicators } & School size (number of pupils) & $\begin{array}{l}1439.5 \\
(600.98)\end{array}$ & $\begin{array}{c}553.4 \\
(408.19)\end{array}$ & $\begin{array}{c}399.1 \\
(224.3)\end{array}$ \\
\hline & Pupil-teacher ratio & $\begin{array}{l}42.23 \\
(24.16)\end{array}$ & $\begin{array}{c}63.62 \\
(55.14)\end{array}$ & $\begin{array}{l}66.1 \\
(40.91)\end{array}$ \\
\hline & $\begin{array}{l}\text { Number of pupils per classroom in } \\
\text { good condition }\end{array}$ & $\begin{array}{l}103.4 \\
(58.41)\end{array}$ & $\begin{array}{l}96.7 \\
(46.40)\end{array}$ & $\begin{array}{l}101.4 \\
(59.66)\end{array}$ \\
\hline \multirow{4}{*}{$\begin{array}{l}\text { Outcome } \\
\text { indicators }\end{array}$} & Repeating the same grade $(\%)$ & $\begin{array}{l}4.9 \\
(4.29)\end{array}$ & $\begin{array}{c}9.42 \\
(6.66)\end{array}$ & $\begin{array}{l}9.1 \\
(5.33)\end{array}$ \\
\hline & $\begin{array}{l}\text { Dropouts as ratio of current } \\
\text { enrolment }(\%)\end{array}$ & $\begin{array}{l}1.67 \\
(2.57)\end{array}$ & $\begin{array}{c}4.49 \\
(5.05)\end{array}$ & $\begin{array}{l}4.6 \\
(5.28)\end{array}$ \\
\hline & $\begin{array}{l}\text { Pass-rate in } 1999 \text { Grade VII } \\
\text { examination (Males) }^{\mathrm{a}}\end{array}$ & $\begin{array}{l}40.5 \\
(22.68)\end{array}$ & $\begin{array}{l}44.2 \\
(27.07)\end{array}$ & $\begin{array}{l}42.6 \\
(27.47)\end{array}$ \\
\hline & $\begin{array}{l}\text { Pass-rate in } 1999 \text { Grade VII } \\
\text { examination (Females) }^{\mathrm{a}}\end{array}$ & $\begin{array}{l}38.6 \\
(24.32)\end{array}$ & $\begin{array}{l}40.7 \\
(30.73)\end{array}$ & $\begin{array}{l}38.4 \\
(30.24)\end{array}$ \\
\hline \multirow{2}{*}{$\begin{array}{l}\text { Pupil } \\
\text { characteristics }\end{array}$} & $\begin{array}{l}\text { Average value of wealth index of } \\
\text { households with children in the } \\
\text { school }^{\mathrm{b}}\end{array}$ & $\begin{array}{c}0.57 \\
(0.61)\end{array}$ & $\begin{array}{r}-0.56 \\
(.56)\end{array}$ & $\begin{array}{l}-0.73 \\
(0.43)\end{array}$ \\
\hline & $\begin{array}{l}\text { Percentage of children who are } \\
\text { orphans }\end{array}$ & $\begin{array}{c}4.7 \\
(3.6)\end{array}$ & $\begin{array}{c}4.79 \\
(4.13)\end{array}$ & $\begin{array}{c}4.9 \\
(3.5)\end{array}$ \\
\hline
\end{tabular}

Note:

a. Pass-Rates are for the Grade VII examination administered to all students by the Examination Council of Zambia.

b. The wealth index is based on a weighted aggregation of household assets similar to a principal components analysis, but with weights optimally derived to minimize classification errors. Details are in Appendix 1 of the text.

Source: ESD Sample. Standard deviations in brackets. 
Table 2: Tracking Resources from District to Schools, 2001-2002

(enrollment weighted Kwacha per pupil)

\begin{tabular}{|c|c|c|c|c|c|c|c|c|c|c|}
\hline & & (1) & (2) & (3) & (4) & (5) & (6) & (7) & (8) & (9) \\
\hline & & $\begin{array}{l}\text { Rule-based }+ \\
\text { discretionary }\end{array}$ & $\begin{array}{c}\text { Discretionary } \\
\text { (province) }\end{array}$ & $\begin{array}{c}\text { Rule-based + } \\
\text { discretionary } \\
(\text { district })\end{array}$ & $\begin{array}{c}\text { Rule-based } \\
\text { (district) }\end{array}$ & $\begin{array}{c}\text { Rule-based + } \\
\text { discretionary } \\
\text { (schools) }\end{array}$ & $\begin{array}{c}\text { Rule-based } \\
+ \\
\text { discretionary } \\
\text { (schools) }\end{array}$ & $\begin{array}{c}\text { Rule-based }+ \\
\text { discretionary } \\
\text { (schools) }\end{array}$ & \multicolumn{2}{|c|}{ Summary } \\
\hline 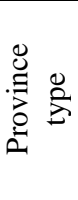 & Province & $\begin{array}{l}\text { Total funds } \\
\text { in the } \\
\text { system }\end{array}$ & $\begin{array}{c}\text { Total } \\
\text { discretionar } \\
\text { y funds } \\
\text { available at } \\
\text { the province } \\
\text { level }\end{array}$ & $\begin{array}{l}\text { Funds at the } \\
\text { district } \\
\text { education } \\
\text { office level }\end{array}$ & $\begin{array}{l}\text { Funds } \\
\text { received } \\
\text { directly } \\
\text { from } \\
\text { ministry }\end{array}$ & $\begin{array}{l}\text { Option 1: } \\
\text { reportedly } \\
\text { passed on to } \\
\text { schools }\end{array}$ & $\begin{array}{l}\text { Option 2: } \\
\text { spending on } \\
\text { schools } \\
\text { (based on } \\
\text { shares) }\end{array}$ & $\begin{array}{l}\text { Option 3: } \\
\text { Funds } \\
\text { reported by } \\
\text { schools }\end{array}$ & $\begin{array}{l}\text { Percent } \\
\text { rule-based } \\
\text { funds that } \\
\text { reach } \\
\text { schools }\end{array}$ & $\begin{array}{c}\text { Percent } \\
\text { discretionar } \\
\text { y funds that } \\
\text { reach } \\
\text { schools }\end{array}$ \\
\hline . & Northern & $\begin{array}{c}29,355 \\
(100)\end{array}$ & $\begin{array}{c}19,779 \\
(67)\end{array}$ & $\begin{array}{c}24,196 \\
(82)\end{array}$ & $\begin{array}{c}9,576 \\
(33)\end{array}$ & $\begin{array}{c}13,618 \\
(46)\end{array}$ & $\begin{array}{c}7,985 \\
(27)\end{array}$ & $\begin{array}{c}9,179 \\
(31)\end{array}$ & 66.6 & 14.1 \\
\hline 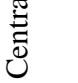 & Eastern & $\begin{array}{c}44,327 \\
(100)\end{array}$ & $\begin{array}{c}29,308 \\
(66)\end{array}$ & $\begin{array}{c}27,437 \\
(62)\end{array}$ & $\begin{array}{c}15,019 \\
(34)\end{array}$ & $\begin{array}{c}15,528 \\
(35)\end{array}$ & $\begin{array}{c}7,408 \\
(17)\end{array}$ & $\begin{array}{c}11,925 \\
(27)\end{array}$ & 44.7 & 17.7 \\
\hline D্] & $\underset{\mathrm{a}}{\text { Copperbelt }}$ & $\begin{array}{c}19,056 \\
(100)\end{array}$ & $\begin{array}{c}4,133 \\
(22)\end{array}$ & $\begin{array}{c}17,263 \\
(91)\end{array}$ & $\begin{array}{c}6,850 \\
(36)\end{array}$ & $\begin{array}{c}9,216 \\
(48)\end{array}$ & $\begin{array}{c}6,215 \\
(33)\end{array}$ & $\begin{array}{c}6,384 \\
(34)\end{array}$ & 44.3 & 27.5 \\
\hline 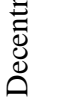 & Lusaka $^{a}$ & $\begin{array}{c}21,842 \\
(100)\end{array}$ & $\begin{array}{c}8,034 \\
(37)\end{array}$ & $\begin{array}{c}20,690 \\
(95)\end{array}$ & $\begin{array}{c}4,057 \\
(19)\end{array}$ & $\begin{array}{c}5,382 \\
(25)\end{array}$ & $\begin{array}{c}2,483 \\
(11)\end{array}$ & $\begin{array}{c}3,121 \\
(14)\end{array}$ & 39.5 & 08.4 \\
\hline
\end{tabular}

Note: Percentages of total funds in brackets. Data exclude two schools in Kafue district, with substantial reported grants not reflected in district data, and most likely outliers linked to measurement problems. Columns (1), (2) and (3) are funds in the system, funds at the province level and total funds at the district level. Column (4) are only the rule-based funds received by the district. Column (5) reported by district, extrapolated from a recall period Jan 2002-July 2002 and from data specifically related to the Zambian Expenditure and Service Delivery Survey sample of schools explicitly asking how much cash was allocated to each school in our sample (for recurrent and capital expenditures). Column (6) reported by district, extrapolated from actual spending data for May 2002. Column (7) based on data collected at the schools level, recall period January 2002-June 2002. Column (8) and Column (9) report the percentage of total rule-based and discretionary funds that schools receive out funds available at the province and district levels. $\left({ }^{\mathrm{a}}\right)$ refers to decentralized districts. 
Table 3a: Disbursement of the Fixed-Grant Allocation

\begin{tabular}{lcccc}
\hline \multirow{2}{*}{ Rule-based funds } & \multicolumn{2}{c}{ Centralized provinces } & \multicolumn{2}{c}{ Decentralized provinces } \\
\cline { 2 - 5 } Percent receiving either $\$ 600$ or $\$ 650$ & 90.39 & 94.87 & 94.12 & 71.3 \\
Percent receiving nothing & 5.77 & 0 & 5.88 & 28.57 \\
Percent receiving less than $\$ 600$ & 3.84 & 5.13 & 0 & 0 \\
\hline
\end{tabular}

Source: Expenditure and Service Delivery Survey data.

Table 3b: Percentage of Schools Receiving No Funds, by Source and Location

\begin{tabular}{|c|c|c|c|c|c|c|}
\hline \multirow[b]{2}{*}{$\begin{array}{l}\text { Funding } \\
\text { category }\end{array}$} & \multirow[b]{2}{*}{ Province } & \multicolumn{2}{|c|}{$\begin{array}{l}\text { Centralized } \\
\text { provinces }\end{array}$} & \multicolumn{2}{|c|}{$\begin{array}{l}\text { Decentralized } \\
\text { provinces }\end{array}$} & \multirow[b]{2}{*}{$\begin{array}{c}\text { All } \\
\text { provinces }\end{array}$} \\
\hline & & Northern & Eastern & Copperbelt & Lusaka & \\
\hline $\begin{array}{l}\text { Rule-based } \\
\text { funding }\end{array}$ & Fixed grant allocation & 5.7 & 0.00 & 5.88 & 28.57 & 10.93 \\
\hline \multirow[t]{4}{*}{$\begin{array}{l}\text { Discretionary } \\
\text { funding }\end{array}$} & $\begin{array}{l}\text { Case I-III donor pool } \\
\text { and domestic } \\
\text { sources }\end{array}$ & 94.2 & 94.8 & 80.00 & 89.1 & 89.2 \\
\hline & Case IV pool: PAGE & 71.15 & 97.44 & 100.00 & 97.06 & 90.66 \\
\hline & $\begin{array}{l}\text { Case IV pool: other } \\
\text { sources }\end{array}$ & 98.00 & 92.31 & 96.00 & 85.29 & 93.96 \\
\hline & Other sources & 98.00 & 97.44 & 98.00 & 85.29 & 95.60 \\
\hline
\end{tabular}

Source: Expenditure and Service Delivery Survey data. 
Table 4: Decomposing Variation in Wealth Within and between Schools (percent)

\begin{tabular}{lcccccc}
\hline & \multicolumn{2}{c}{ Variation Within } & \multicolumn{3}{c}{ Variation Between } \\
\cline { 2 - 7 } & $\begin{array}{c}\text { Full } \\
\text { sample }\end{array}$ & $\begin{array}{c}\text { Rural } \\
\text { sample }\end{array}$ & $\begin{array}{c}\text { Remote } \\
\text { sample }\end{array}$ & $\begin{array}{c}\text { Full } \\
\text { sample }\end{array}$ & $\begin{array}{c}\text { Rural } \\
\text { Sample }\end{array}$ & $\begin{array}{c}\text { Remote } \\
\text { sample }\end{array}$ \\
\hline \multirow{2}{*}{ Asset index } & 34.30 & 55.50 & 49.30 & 65.70 & 44.40 & 50.70 \\
Random variation & 94.20 & 94.80 & 92.10 & 5.70 & 5.10 & 7.90 \\
\hline
\end{tabular}

Note: The decomposition is based on the asset index described in Appendix 1. The second row, random variation, shows the decomposition if wealth were distributed randomly, and provides a benchmark comparison given the small sample sizes in the schools. For the random variation, wealth was assumed to be normally distributed with the same mean and standard deviation as the asset index.

Source: Expenditure and Service Delivery Survey data. 
Table 5a: Relationship between Household and School Funding

\begin{tabular}{|c|c|c|c|c|}
\hline & $(1)$ & $(2)$ & (3) & $(4)$ \\
\hline & Tobit specification & $\begin{array}{c}\text { Tobit with random } \\
\text { effects }\end{array}$ & $\begin{array}{c}\text { Test of weak } \\
\text { exogeneity: Tobit }\end{array}$ & $\begin{array}{c}\text { Test of weak } \\
\text { exogeneity: Tobit } \\
\text { with random } \\
\text { effects }\end{array}$ \\
\hline $\begin{array}{l}\text { Log rule-based } \\
\text { funds }\end{array}$ & $\begin{array}{l}-\mathbf{0 . 5 6 7} \\
{[\mathbf{0 . 1 4 2}]^{* *}}\end{array}$ & $\begin{array}{l}-\mathbf{0 . 5 7 2} \\
{[0.160]^{* *}}\end{array}$ & $\begin{array}{l}-0.759 \\
{[0.298]^{*}}\end{array}$ & $\begin{array}{l}-\mathbf{0 . 7 6 3} \\
{[0.332]^{*}}\end{array}$ \\
\hline $\begin{array}{l}\text { Log discretionary } \\
\text { funds }\end{array}$ & $\begin{array}{c}-0.079 \\
{[0.058]}\end{array}$ & $\begin{array}{l}-\mathbf{0 . 0 7 9} \\
{[0.065]}\end{array}$ & $\begin{array}{c}-\mathbf{0 . 0 7 7} \\
{[\mathbf{0 . 0 5 6}]}\end{array}$ & $\begin{array}{l}-\mathbf{0 . 0 7 7} \\
{[0.062]}\end{array}$ \\
\hline $\begin{array}{l}\text { Residual from } \\
\text { "selection" } \\
\text { equation }\end{array}$ & & & $\begin{array}{c}0.235 \\
{[0.343]}\end{array}$ & $\begin{array}{c}0.232 \\
{[0.383]}\end{array}$ \\
\hline Gender of child & $\begin{array}{l}-0.049 \\
{[0.124]}\end{array}$ & $\begin{array}{l}-0.048 \\
{[0.123]}\end{array}$ & $\begin{array}{l}-0.050 \\
{[0.123]}\end{array}$ & $\begin{array}{l}-0.050 \\
{[0.123]}\end{array}$ \\
\hline Age of child & $\begin{array}{l}0.293 \\
{[0.021]^{* *}}\end{array}$ & $\begin{array}{l}0.293 \\
{[0.021]^{* *}}\end{array}$ & $\begin{array}{l}0.293 \\
{[0.021]^{* *}}\end{array}$ & $\begin{array}{l}0.293 \\
{[0.021]^{* *}}\end{array}$ \\
\hline $\begin{array}{l}\text { Household wealth } \\
\text { index }\end{array}$ & $\begin{array}{l}0.726 \\
{[0.080]^{* *}}\end{array}$ & $\begin{array}{l}0.723 \\
{[0.080]^{* *}}\end{array}$ & $\begin{array}{l}0.726 \\
{[0.080]^{* *}}\end{array}$ & $\begin{array}{c}0.724 \\
{[0.080]^{* *}}\end{array}$ \\
\hline Mean village wealth & $\begin{array}{c}0.007 \\
{[0.203]}\end{array}$ & $\begin{array}{l}-0.003 \\
{[0.225]}\end{array}$ & $\begin{array}{l}-0.015 \\
{[0.188]}\end{array}$ & $\begin{array}{l}-0.021 \\
{[0.206]}\end{array}$ \\
\hline Constant & $\begin{array}{l}10.214 \\
{[1.320]^{* *}}\end{array}$ & $\begin{array}{l}10.264 \\
{[1.486]^{* *}}\end{array}$ & $\begin{array}{l}11.834 \\
{[2.722]^{* *}}\end{array}$ & $\begin{array}{l}11.860 \\
{[3.034] * *}\end{array}$ \\
\hline Observations & 1,410 & 1,410 & 1,410 & 1,410 \\
\hline
\end{tabular}

Note: The regressions in this table show the effect of anticipated and unanticipated funding on children's educational expenditures (the dependant variable in all regressions). Estimates marked ** are significant at 1 percent, $*$ denotes significance at 5 percent and standard errors are presented in [brackets]. Columns (1) and (2) present the estimates from the Tobit and the random-effects Tobit specificatons. Columns (3) and (4) present the test of weak exogeneity (Blundell and Smith, 1986) where the residual from the first stage regression determining log anticipated funds is included as an additional regressor. All regressions control for the mean wealth of students in the school, province dummies and a rural dummy. The censoring is at 0 for the Tobit and the random effects Tobit specifications account for the clustering of errors at the level of the village. Marginal effects (conditional on being uncensored) and the probability of censoring are presented in Table $5 \mathrm{~b}$.

a. For all regressions, K100 is added to zero values of discretionary funding to allow logs. The minimum funding is K900 conditional on receipt

b. Two private schools are excluded from the analysis.

c. K50 is added to enrolled children with zero educational expenditures who form 4.96 percent of the sample

d. The wealth index is based on optimal maximum likelihood weights (see Appendix 1). Results are robust to alternative indices (for instance an unweighted raw sum). 
Table 5b: Marginal Effects and Probability of Censoring

\begin{tabular}{|c|c|c|c|c|}
\hline & \multicolumn{2}{|c|}{ (1) } & \multicolumn{2}{|c|}{ (2) } \\
\hline & \multicolumn{2}{|c|}{ Tobit specification } & \multicolumn{2}{|c|}{ Tobit with random effects } \\
\hline & $\begin{array}{c}\text { Marginal effect } \\
\text { at mean }\end{array}$ & $\begin{array}{c}\text { Prob. } \\
\text { (uncensored) }\end{array}$ & $\begin{array}{c}\text { Marginal effect } \\
\text { at mean }\end{array}$ & $\begin{array}{c}\text { Prob. } \\
\text { (uncensored) }\end{array}$ \\
\hline Log rule-based funds & $\begin{array}{l}-0.46 \\
{[0.11]^{* *}}\end{array}$ & $\begin{array}{l}-0.024 \\
{[0.006]^{* *}}\end{array}$ & $\begin{array}{l}-0.52 \\
{[0.146]^{* *}}\end{array}$ & $\begin{array}{l}-0.038 \\
{[0.010]^{* *}}\end{array}$ \\
\hline $\begin{array}{l}\text { Log discretionary } \\
\text { funds }\end{array}$ & $\begin{array}{r}-0.06 \\
{[.047]}\end{array}$ & $\begin{array}{l}-0.003 \\
{[0.002]}\end{array}$ & $\begin{array}{l}-0.07 \\
{[0.059]}\end{array}$ & $\begin{array}{l}-0.005 \\
{[0.004]}\end{array}$ \\
\hline
\end{tabular}

Note: This table shows the marginal effects at mean values of the regressors based on the coefficients from Table 5a. In all cases, the significance of estimated coefficients is robust to clustering at the village level. 


\begin{tabular}{lll} 
A.1: Asset Items for & Household Wealth Index & \\
\hline Asset number (for graphs) & Descriptions of asset & Used for \\
\hline Item1 & Is house made of brick? & All sample \\
Item2 & Does house have electricity? & All sample \\
Item3 & Does household own TV? & All sample \\
Item4 & Does household own radio-cassette? & All sample \\
Item5 & Does household own radio? & All sample \\
Item6 & Does household own video? & All sample \\
Item7 & Does household own sewing & All sample \\
& machine? & \\
Item8 & Does household own stove/cooker? & All sample \\
Item9 & Does household own fridge/freezer? & All sample \\
Item10 & Does household use plough? & Rural only \\
Item11 & Does household use crop sprayer? & Rural only \\
Item12 & Does household use hammer mill? & Rural only \\
Item13 & Does household use hand-grinding & Rural only \\
Item14 & mill? & \\
Item15 & Does household use tractor? & Rural only \\
Item16 & Does household own cattle? & Rural only \\
\hline
\end{tabular}

\section{A.2: Asset Item for School Wealth Index}

\begin{tabular}{lll}
\hline Asset number & Descriptions of asset & Used for \\
\hline Item1 & Is house made of brick? & All sample \\
Item2 & Does house have electricity? & All sample \\
Item3 & Does household own TV? & All sample \\
Item4 & Does household own radio-cassette? & All sample \\
Item5 & Does household own radio? & All sample \\
Item6 & Does household own video? & All sample \\
Item7 & Does household own sewing & All sample \\
& machine? & \\
Item8 & Does household own stove/cooker? & All sample \\
Item9 & Does household own fridge/freezer? & All sample \\
\hline
\end{tabular}

